\title{
Aktywność procesów osuwiskowych na wybrzeżu klifowym wyspy Wolin w warunkach oddziały wania zdarzeń hydrometeorologicznych o wysokim potencjale morfogenetycznym (Zatoka Pomorska - Baltyk Południowy)
}

\author{
The activity of landslides on the cliff coast on the Wolin Island under the influence of \\ hydrometeorological events with high morphogenetic potential (Bay of Pomerania - \\ Southern Baltic)
}

\author{
Marcin Winowski \\ Instytut Geoekologii i Geoinformacji, Uniwersytet im. Adama Mickiewiczaw Ponaniu; e-mail: marwin@amu.edu.pl
}

Zarys treści: Artykuł prezentuje wyniki badań nad aktywnością procesów osuwiskowych na wybrzeżu klifowym wyspy Wolin wywołanych silnymi wezbraniami sztormowymi oraz intensywnymi opadami atmosferycznymi. Badania opierały się na studium pięciu przypadków dotyczących wykształcenia lub przeobrażenia osuwisk klifowych. W wyniku przeprowadzonej analizy zaproponowane zostały wartości progowe odporności systemu stokowego na oddziaływanie takich czynników morfogenetycznych jak wezbrania sztormowe i opady atmosferyczne. W przypadku przekroczenia wymienionego czynnika wartości progowej w obrębie klifu dochodzi do wykształcenia osuwiska. Należy nadmienić, iż inicjacja procesu osuwiskowego warunkowana jest także wieloma innymi czynnikami, które najczęściej mają charakter wybitnie lokalny (morfologia, litologia, hydrogeologia, itd.). Wobec powyższego należy stwierdzić, iż przedstawione wartości progowe są wartościami koniecznymi do wystąpienia procesów osuwiskowych, jednak z uwagi na złożoność tych procesów, w niektórych przypadkach mogą one nie stanowić wartości wystarczających.

Slowa kluczowe: Wybrzeże klifowe, osuwiska klifowe, sztormy, opady, wartości progowe

\begin{abstract}
The paper presents results of research on the activity of landslides on the Wolin Island cliff coast caused by storm surges and intense rainfall events. The study was based on the analysis of five cases of initiation or transformation of cliff landslides. As a result of the analysis the treshold values of storm surges and precipitation were proposed. Exceeding the threshold values results in a landslide. It should be noted that the process of landslide initiation is conditioned also by many other factors that are most often very local (cliff morphology, lithology, hydrogeology etc.). Therefore, it must be concluded that proposed threshold values are necessary for the occurrence of landslides, but due to the complexity of these processes, in some cases, they may not provide sufficient value.
\end{abstract}

Key words: cliff coast, cliff landslides, storm surges, precipitation, tresholds

\section{Wprowadzenie}

Zachodzące w środowisku zmiany klimatyczne są w świecie naukowym powszechnie przyjętą hipotezą. Bez względu na to czy warunkowane są działalnością człowieka czy też stanowią naturalny ciąg wahań klimatycznych, powodują wzrost występowania zdarzeń meteoro- logicznych o wysokim natężeniu (IPCC 2007). Zjawiska te bardzo często przejawiają się jako lokalne lub regionalne zdarzenia ekstremalne. Występowanie tego rodzaju procesów wiąże się ze znaczną ingerencją w aktualny stan systemu morfogenetycznego naszej planety. Procesy o charakterze ekstremalnym, wywierają istotny wpływ na rozmieszczenie oraz aktualny stan geoekosystemów. Na- 
ruszają one równowagę geoekosystemów, a jednocześnie są bardzo ważnym przejawem ich funkcjonowania.

Procesy o charakterze ekstremalnym mają niewątpliwie duży wpływ na rozwój strefy brzegowej, są najczęściej czynnikiem inicjującym rozwój wybrzeży morskich, w tym głównie klifowych (Jania, Zwoliński 2011). Coraz częściej w okresie jesiennym i zimowym nad Europą wędrują głębokie ośrodki niżowe, które na obszarze wybrzeża Polski powodują silne wiatry i niekiedy nawalne opady (Bielec-Bakowska, Lupikasza 2009, Dreier i in. 2013, Tylkowski 2013, Wolski, Wiśniewski 2014). W efekcie oddziaływania morza i czynników pogodowych, na zboczach klifowych obserwuje się intensyfikację ruchów masowych (Winowski 2009). W skutek tego dochodzi do powstawania osuwisk o różnym zasięgu przestrzennym, co w wielu przypadkach niesie ze sobą nie tylko duże zniszczenia brzegu ale także zagrożenie dla gospodarki ludzi zamieszkujących tereny nadmorskie.

Występowanie tych, jakże niekorzystnych zdarzeń geomorfologicznych skłania do dokładnego rozpoznania natury procesów osuwiskowych oraz ustalenia wartości progowych czynników pogodowych i dynamiki morza, po przekroczeniu których dochodzi do uruchomienia osuwiska. Wyznaczone wartości progowe stanowią cenne narzędzie w zarządzaniu strefą brzegową oraz konstruowaniu modeli systemu ostrzegawczego przed niebezpiecznymi zdarzeniami geomorfologicznymi w tej strefie.

Wobec powyższego należy stwierdzić, iż głównym celem pracy jest określenie wpływu czynników hydrometeorologicznych o wysokim potencjale morfogenetycznym na powstawanie i rozwój osuwisk klifowych oraz przedstawienie wartości progowych, po przekroczeniu których w obrębie klifu dochodzi do uruchomienia osuwiska.

\section{Material i metody}

W celu realizacji założonego problemu badawczego zaplanowano i przeprowadzono postępowanie badawcze (ryc. 1). W początkowym etapie skartowano wszystkie formy osuwiskowe występujące na badanym obszarze, spośród których do badań szczegółowych wytypowano pięć osuwisk różniących się morfologią, litologią oraz stopieniem utrwalenia (ryc. 2). W kolejnym etapie określono wiek oraz genezę badanych osuwisk. Badania te opierały się na analizach dendrochronologicznych. Polegały one na analizie przyrostów słoi odsłoniętych korzeni drzew porastających krawędzie nisz osuwiskowych (Buchwał, Winowski 2009). Do badań szczegółowych pobrano korzenie buka (Fagus silvatica L.). Następnie na pobranych próbkach przeprowadzono analizę mikroskopową rocznych przyrostów komórek drewna stosując metodykę opisaną przez Schwiengrubera (1978, 2007) i Gärtnera (2003). Analiza zmian anatomicznych w korzeniu zmierzała do wychwycenia roku, w którym zapisana została nagła redukcja wielkości naczyń w drewnie oraz zmiana struktury, w której zauważono transforma-

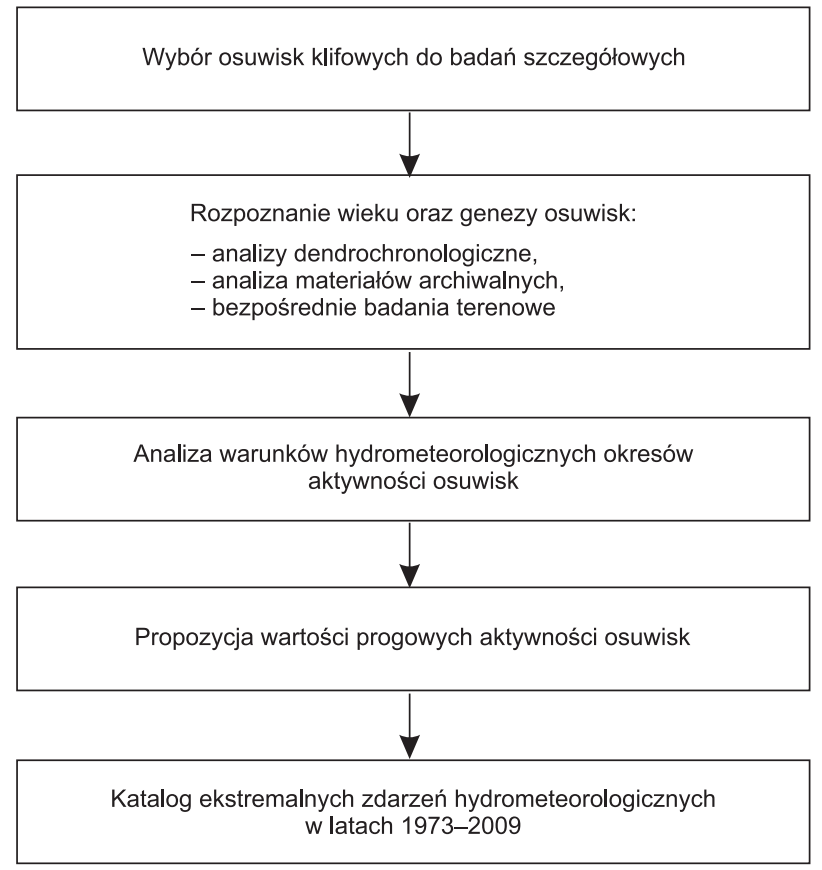

Ryc. 1. Etapy postępowania badawczego

Fig. 1. Stages of research

cje rozmieszczenia naczyń w słojach przyrostu rocznego z rozpierzchłonaczyniowej do pierścienionaczyniowej.

Z uwagi na dostępność materiału badawczego, datowania dendrochronologiczne zostały przeprowadzone na osuwisku I i IV. Wiek osuwiska V określony został na podstawie analizy dokumentacji fotograficznej zgromadzonej przez Zbigniewa Zwolińskiego i Andrzeja Kostrzewskiego (Uniwersytet im. Adama Mickiewicza w Poznaniu). Powstanie osuwiska II i III udokumentowane zostało w toku bezpośrednich obserwacji terenowych. W kolejnym etapie postępowania badawczego przeprowadzono analizę warunków hydrometeorologicznych okresów, w których doszło do wykształcenia lub odświeżenia analizowanych osuwisk i na jej podstawie wyznaczono wartości progowe (dla poziomu morza i opadów atmosferycznych) po przekroczeniu, których dochodzi do wystąpienia procesu osuwiskowego. Za wartość progową uznano najniższą wartość czynnika morfogenetycznego, która doprowadziła do zainicjowania procesu osuwiskowego. Dane dotyczące poziomu morza oraz opadów atmosferycznych obejmowały wielolecie 1973-2009 i pozyskane zostały ze stacji meteorologicznej Instytutu Meteorologii i Gospodarki Wodnej w Świnoujściu. Ponadto w celu scharakteryzowania epizodu aktywności osuwisk z kwietnia 2008 roku wykorzystano także dane ze stacji meteorologicznej w Białej Górze. Należy nadmienić, iż stacja meteorologiczna w Białej Górze znajduje się w bliskim sąsiedztwie korony klifu co sprawia, iż prowadzone tam pomiary cechują się największą reprezentatywnością w kontekście badań procesów brzegowych wyspy Wolin. Niestety z uwagi na fakt, iż stacja meteorologiczna w Białej Górze posiada stosunkowo krótką serię pomiarową niemożliwe staje się przeprowadzenie analiz starszych epizodów aktywności osuwisk. Pomierzone wysokości 


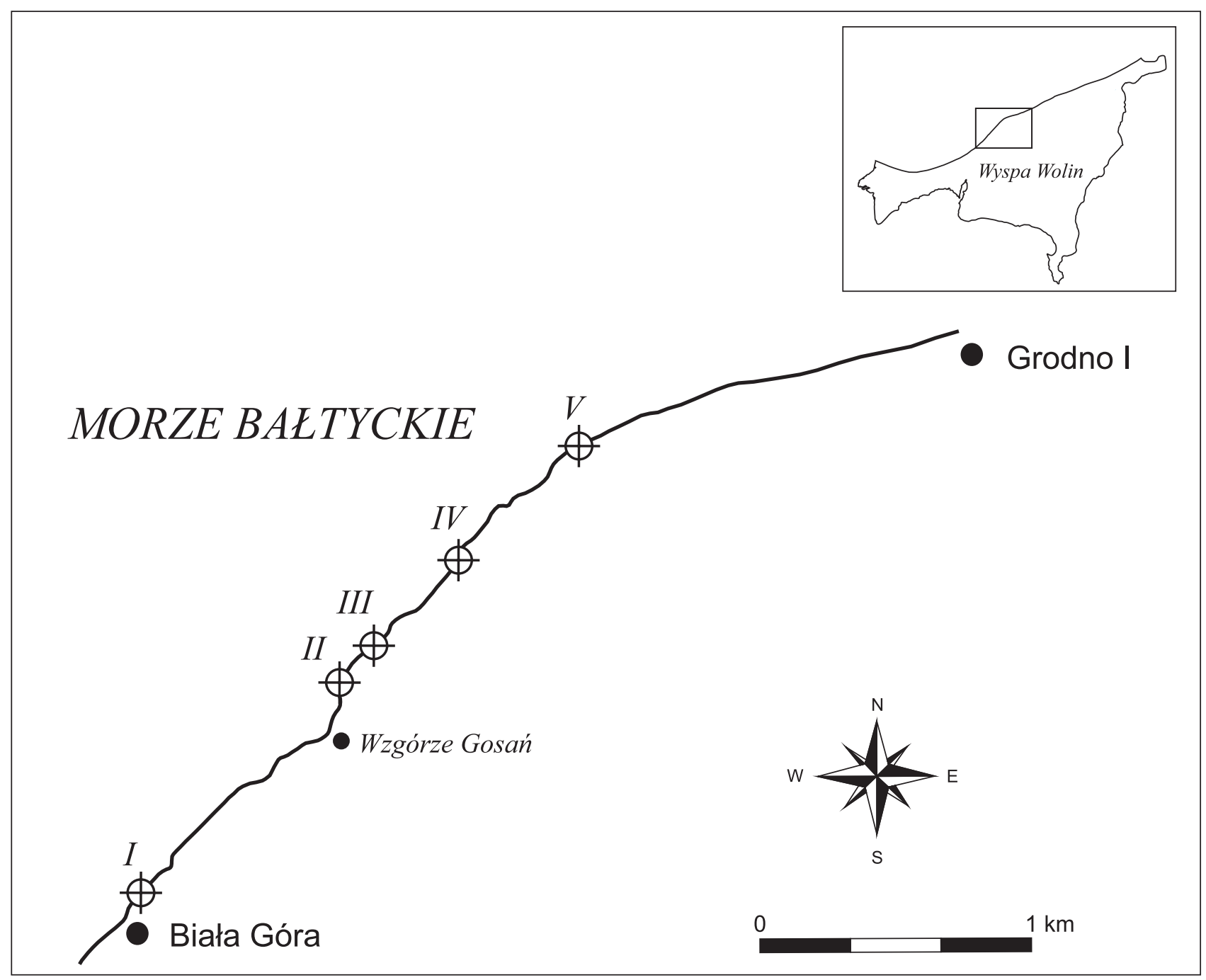

Ryc. 2. Lokalizacja badanych osuwisk

Fig. 2. Location of studied landslides

opadów atmosferycznych w stacji w Świnoujściu i Białej Górze cechują się dużą zbieżnością. Współczynnik korelacji opadów z kwietnia 2008 roku dla stacji w Świnoujściu i w Białej Górze wyniósł 0,93.

Końcowym etapem realizowanych badań było przedstawienie katalogu ekstremalnych zdarzeń hydrometeorologicznych z okresu 1973-2009, których parametry spełniały kryteria przedstawionych wartości progowych, które wstępnie przedstawiono w pracy Kostrzewskiego i in. 2015.

\section{Obszar badań}

Badania prowadzące do określenia wpływu ekstremalnych zdarzeń hydrometeorologicznych na intensyfikację procesów osuwiskowych przeprowadzone zostały na wybrzeżu klifowym wyspy Wolin (Bałtyk Południowy Zatoka Pomorska) (ryc. 1). Klify Wolina rozciągają się na odcinku 11,5 km. Graniczą one od zachodu z ciągiem wydm położonych na Mierzei Świny w okolicach Świ- noujścia zaś od wschodu z ciągiem wydm położonych na Mierzei Dziwny w okolicach Dziwnowa.

Analizowany odcinek klifu powstał na skutek podcięcia wolińskiej moreny czołowej przez transgredujące Morze Bałtyckie. W efekcie tego doszło do wykształcenia klifów morenowych, które mają duże zróżnicowanie morfologiczne i litologiczne o wysokości przekraczającej w kilku miejscach $90 \mathrm{~m}$ oraz nachyleniu stoku 40-90 ${ }^{\circ}$. Badany odcinek wybrzeża klifowego pełni różne funkcje morfodynamiczne. Wyróżnić można tutaj klify o wysokiej aktywności morfodynamicznej oraz odcinki klifowe znajdujące się w stadium zamierania. Najważniejszym czynnikiem decydującym o przekształcaniu rzeźby omawianych klifów są niewątpliwie ruchy masowe, wśród których istotną rolę pełnią procesy osuwiskowe.

Jak już zostało wspomniane realizacja założonego problemu badawczego została przeprowadzona w oparciu o analizę aktywności pięciu osuwisk klifowych zróżnicowanych za względu na morfologię, litologię oraz stopień utrwalenia.

Osuwisko I zlokalizowane zostało w sąsiedztwie Stacji Monitoringu Środowiska Przyrodniczego w Bia- 

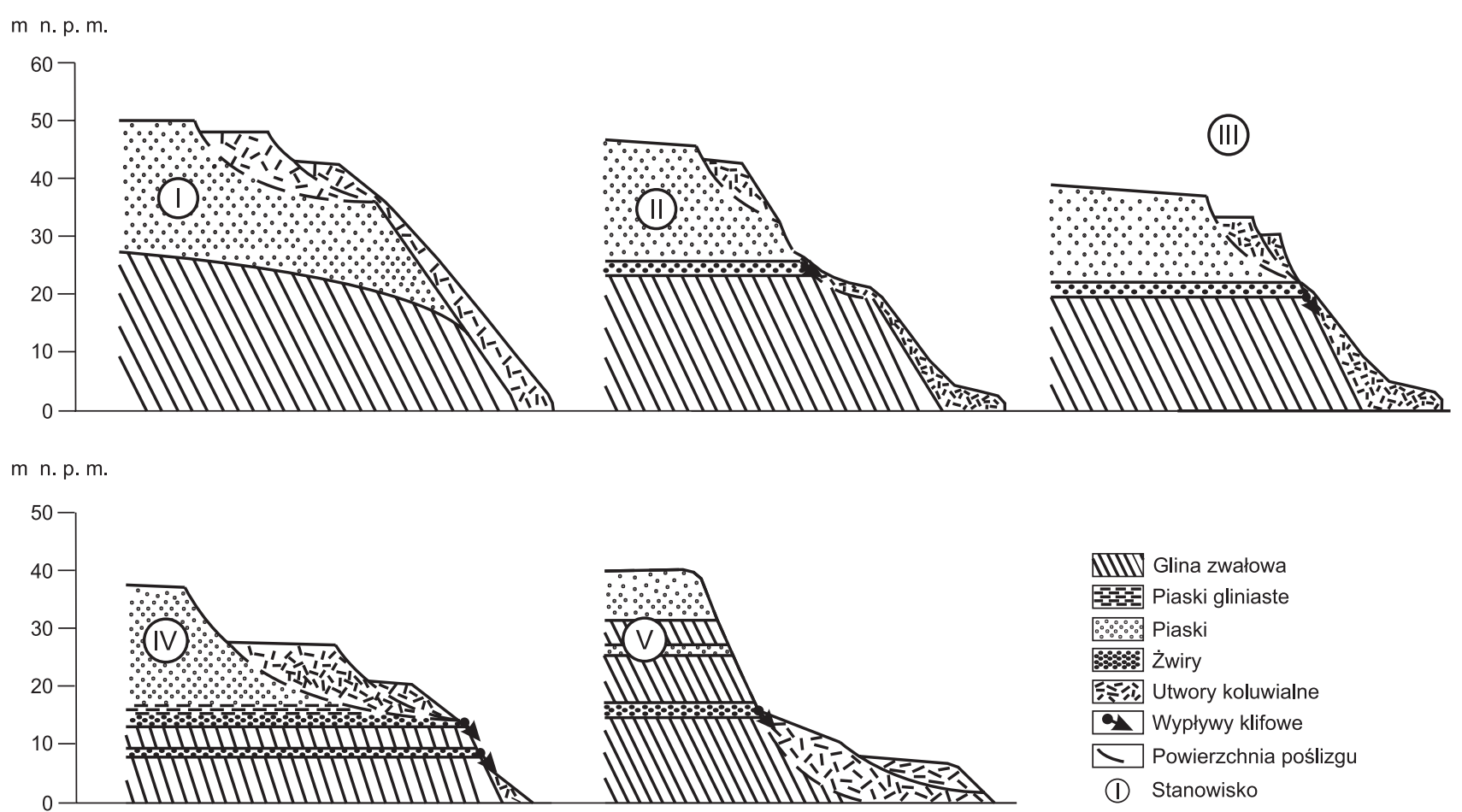

Ryc. 3. Ogólny szkic litologiczny badanych odcinków klifowych

Fig. 3. General sketch of lithology for studied cliff sections

łej Górze, 2 km na wschód od Międzyzdrojów (ryc. 2). Klif w tej części wybrzeża wznosi się do wysokości $50 \mathrm{~m}$ n.p.m. W części spągowej klifu do wysokości 25 m n.p.m. występują pokłady szarej gliny zwałowej ze zlodowacenia środkowopolskiego. Strop tej serii opada w kierunku północno-zachodnim i pojawia się na ścianie klifu na wysokości ok. 15 m n.p.m. Na pokładach gliny morenowej zdeponowane zostały piaski fluwioglacjalne oraz leżące powyżej eoliczne piaski pokrywowe, w obrębie których w postaci wyraźnego stopnia wykształcone zostało osuwisko o powierzchni $110 \mathrm{~m}^{2}$. Omawiane osuwisko przybrało postać rozciągniętą w osi NW-SE. W części krawędziowej stopnia osuwiska doszło do wykształcenia mniejszych form osuwiskowych, które są przejawem postępującej dezintegracji koluwium. Bezpośrednio na skłonie klifu, poniżej osuwiska spoczywa miąższa pokrywa piaszczystych utworów koluwialnych będąca produktem niszczenia górnej partii klifu. Seria tych utworów stanowi podparcie dla zalegającego na zapleczu klifu osuwiska (ryc. 3). Czasami w okresach sztormowych na skutek abrazyjnego podcięcia utworów podstokowych dochodzi do odświeżenia analizowanego osuwiska.

Osuwisko II powstało w obrębie klifu piaszczysto-gliniastego, zlokalizowanego $100 \mathrm{~m}$ na wschód od punktu widokowego na Wzgórzu Gosań (ryc. 2). Podobnie jak w przypadku osuwiska I tak i w tym w spagowej partii występują gliny zwałowe, które na wysokości ok. $30 \mathrm{~m}$ przechodzą $\mathrm{w}$ utwory piaszczyste o miąższości ponad 20 $\mathrm{m}$. W strefie kontaktu serii gliniastej i piaszczystej występuje warstwa żwirów o niewielkiej miąższości (ok. 30 $\mathrm{cm}), \mathrm{z}$ której w okresach deszczowych wypływają wody gruntowe. Występowanie wód gruntowych przyczyniło się na tym odcinku klifu do zainicjowania procesu osuwi- skowego, poprzez ścięcie utworów piaszczystych. Dzięki temu w środkowej partii klifu doszło do wykształcenia dość płytkiego osuwiska. Osunięty po stoku materiał utworzył na poziomie plaży rozległy jęzor osuwiskowy o objętości $380 \mathrm{~m}^{3}$ (Winowski 2008). Ubytek tak znacznej ilości materiału ze środkowej partii klifu przyczynił się do destabilizacji strefy przykoronkowej. W efekcie tego doszło do uruchomienia kolejnej formy osuwiskowej w postaci zerwy (ryc. 3).

Osuwisko III zlokalizowane zostało ok. $100 \mathrm{~m}$ na wschód od osuwiska II (ryc. 2). Zostało ono wykształcone w osadach piaszczystych spoczywających na pokładach gliny zwałowej. Jest to osuwisko o niewielkich rozmiarach dochodzących do $50 \mathrm{~m}^{2}$, które powstało w środkowej partii klifu w efekcie ścięcia osadów piaszczystych. Przemieszczone osady zdeponowane zostały u podnóża klifu w formie niewielkiego jęzora osuwiskowego (ryc. 3).

Osuwisko IV powstało w obrębie klifu piaszczysto-gliniastego znajdującego się w okolicy rezerwatu ochrony ścisłej im. Prof. Zygmunta Czubińskiego $1 \mathrm{~km}$ na wschód od Wzgórza Gosań (ryc. 2). W spągowej partii klifu występują gliny zwałowe ze zlodowacenia środkowopolskiego o miąższości dochodzącej do $12 \mathrm{~m}$. Na utworach gliniastych zdeponowana została miąższa warstwa utworów piaszczystych (ok. $25 \mathrm{~m}$ ). W strefie kontaktu serii piaszczystej i gliniastej występuje również wkładka żwirów o miąższości 40-50 cm, w obrębie której w okresach deszczowych zaznaczają się wypływy klifowe o niewielkiej wydajności (1-2 $\left.\mathrm{dm}^{3} / \mathrm{min}\right)$. Występowanie w tej części klifu wód gruntowych zwiększa predyspozycje do uruchomienia procesów osuwiskowych w obrębie wyżej leżącej serii piaszczystej. Przejawem tego procesu jest 
występujące w górnej partii klifu wyraźnie zestopniowane osuwisko IV o powierzchni $660 \mathrm{~m}^{2}$ (ryc. 3).

Osuwisko V zlokalizowane zostało w obrębie Świdnej Kępy ok. 1,5 km na zachód od Grodna (ryc. 2). Klif w tej części wybrzeża wznosi się na wysokość ok. $40 \mathrm{~m}$ i w większości zbudowany jest z gliny zwałowej z piaszczystym nadkładem o miąższości ok. $5 \mathrm{~m}$. Seria glin morenowych przełożona została w wielu miejscach utworami piaszczystymi i żwirowymi, które zwłaszcza na wysokości 15-17 m n.p.m. warunkują występowanie wypływów wód gruntowych o charakterze wysięków (ryc. 3). Analizowany odcinek wybrzeża charakteryzuje się najdogodniejszą ekspozycją na podejście fali morskiej spośród wszystkich obserwowanych. Dzięki temu zachodzą tutaj najintensywniejsze procesy abrazji morskiej, które podcinając klif inicjują procesy osuwiskowe. Przejawem tego jest funkcjonujące w tej części klifu osuwisko o powierzchni dochodzącej do $1000 \mathrm{~m}^{2}$. Koluwium przybrało tutaj postać wyraźnego stopnia ponacinanego licznymi spękaniami powstałymi w wyniku oddziaływania potomnych ruchów osuwiskowych. W jego budowie dominują utwory gliniaste dość mocno przemieszane z osadami piaszczystymi. Indywidualność tego osuwiska przejawia się w występowaniu znacznej ilości wody gruntowej pochodzącej z wypływów klifowych, która infiltrując w koluwium przyczynia się do wzmożonej erozji wodnej. Dzięki temu analizowane osuwisko jest aktualnie dość mocno zdegradowane.

\section{Wyniki}

\section{Geneza osuwisk}

Badania dotyczące genezy osuwisk, o czym wspomniano w poprzednim rozdziale realizowane były w dwóch etapach. W pierwszym etapie określany był wiek osuwiska (analiza dendrochronologiczna, analiza dokumentacji fotograficznej, bezpośrednie obserwacje terenowe), zaś w drugim na podstawie analizy warunków mareograficznych oraz opadowych okresów, w których osuwiska wykazywały aktywność rozpoznana była ich geneza. Analizy dendrochronologiczne pozwoliły określić wiek osuwiska I i IV.

Na osuwisku I, w górnej części niszy osuwiskowej, pobranych zostało 12 próbek korzeni drzew. Jedna próbka wskazywała, iż odsłonięcie korzenia wystąpiło w roku 1995. Przyjęto, iż okres ten odpowiedzialny jest za inicjację osuwiska. W przypadku dziewięciu kolejnych próbek zmiany anatomiczne drewna przypadały na rok 2001, zaś w dwóch ostatnich na rok 2006. Dwie ostatnie daty powiązane zostały $\mathrm{z}$ epizodem odświeżenia osuwiska i znacznym rozwinięciem niszy osuwiskowej. Należy zaznaczyć, iż eksponowane korzenie buka są bardzo mało odporne na oddziaływanie czynników zewnętrznych. Sytuacja taka może tłumaczyć małą ilość korzeni przetrwałych od 1995 roku. Niewielka liczba próbek wskazująca rok 2006 sugeruje, że proces odświeżenia osuwiska nie był tak znaczący jak w roku 2001. Konfrontacja uzyskanych dat $\mathrm{z}$ danymi hydrometeorologicznymi pozwoliła stwierdzić, iż analizowane osuwisko ma genezę sztormową i kształtowane było w trakcie następujących epizodów sztormowych: listopad 1995, listopad 2001, listopad 2006 czego dowodzą analizy warunków mareograficznych z tych okresów.

W przypadku osuwiska IV udało się pozyskać tylko 3 próbki korzeni z górnej części niszy osuwiskowej. Ich analiza jednoznacznie wykazała, iż do wykształcenia niszy osuwiskowej doszło w 1976 roku. Analiza panujących wówczas warunków hydrometeorologicznych pozwoliła stwierdzić, iż omawiane osuwisko powstało w wyniku intensywnych opadów atmosferycznych. Ponadto bezpośrednie obserwacje terenowe dowiodły, iż osuwisko IV zostało odświeżone w efekcie wystąpienia intensywnych opadów atmosferycznych w maju 2008 roku.

Wiek osuwiska II i III udokumentowany został w trakcie bezpośrednich badań terenowych. Analizowane obiekty mają najmniejsze rozmiary spośród wszystkich badanych (II - $180 \mathrm{~m}^{2}$, III $-50 \mathrm{~m}^{2}$ ) przez co są one najbardziej czułymi na wszelkie zdarzenia hydrometeorologiczne o podwyższonym potencjale morfogenetycznym. Genezę swą zawdzięczają intensywnym opadom atmosferycznym z lipca 2007 roku (osuwisko II) i kwietnia 2008 (osuwisko III).

Geneza osuwiska V została ustalona na podstawie analiz dokumentacji fotograficznej zgromadzonej przez Zbigniewa Zwolińskiego i Andrzeja Kostrzewskiego z Uniwersytetu im. Adama Mickiewicza w Poznaniu. Przeprowadzone analizy wykazały, iż osuwisko V powstało w efekcie dużego spiętrzenia sztormowego w listopadzie 1995 roku. Osuwisko to zostało także przemodelowane w trakcie opadów atmosferycznych w kwietniu 2008 roku.

Z przeprowadzonych analiz wynika, iż do powstania lub odświeżenia osuwisk na wybrzeżu klifowym wyspy Wolin na skutek wezbrań sztormowych dochodziło w latach 1995, 2001 oraz 2006, zaś opady atmosferyczne kształtowały osuwiska w latach 1975, 2007, 2008. Poniżej w kolejności chronologicznej przedstawiona została charakterystyka warunków hydrometeorologicznych, w trakcie których obserwowane osuwiska poddawane były procesom inicjacji i odświeżania.

\section{Wpływ wezbrań sztormowych oraz opadów atmosferycznych na aktywność procesów osuwiskowych w okresie 1973-2009}

\section{Epizod I - Październik 1976}

Z epizodem z 1976 związana była inicjacja osuwiska IV, do czego doszło w efekcie wystapienia intensywnych opadów atmosferycznych. Suma opadów zarejestrowana w październiku 1976 roku wyniosła $109 \mathrm{~mm}$ i na tle wielolecia była wyższa od średniej dla tego miesiąca o $242 \%$. W okresie tym opad rejestrowany był w trakcie $11 \mathrm{dni}$, z czego 9 dni przypadło na pierwszą połowę miesiąca (ryc. 4). W okresie od 3 do 17 października wystąpił opad, którego suma wyniosła $104 \mathrm{~mm}$. Wartość ta stanowiła 95\% wszystkich opadów analizowanego miesiąca. W okresie 


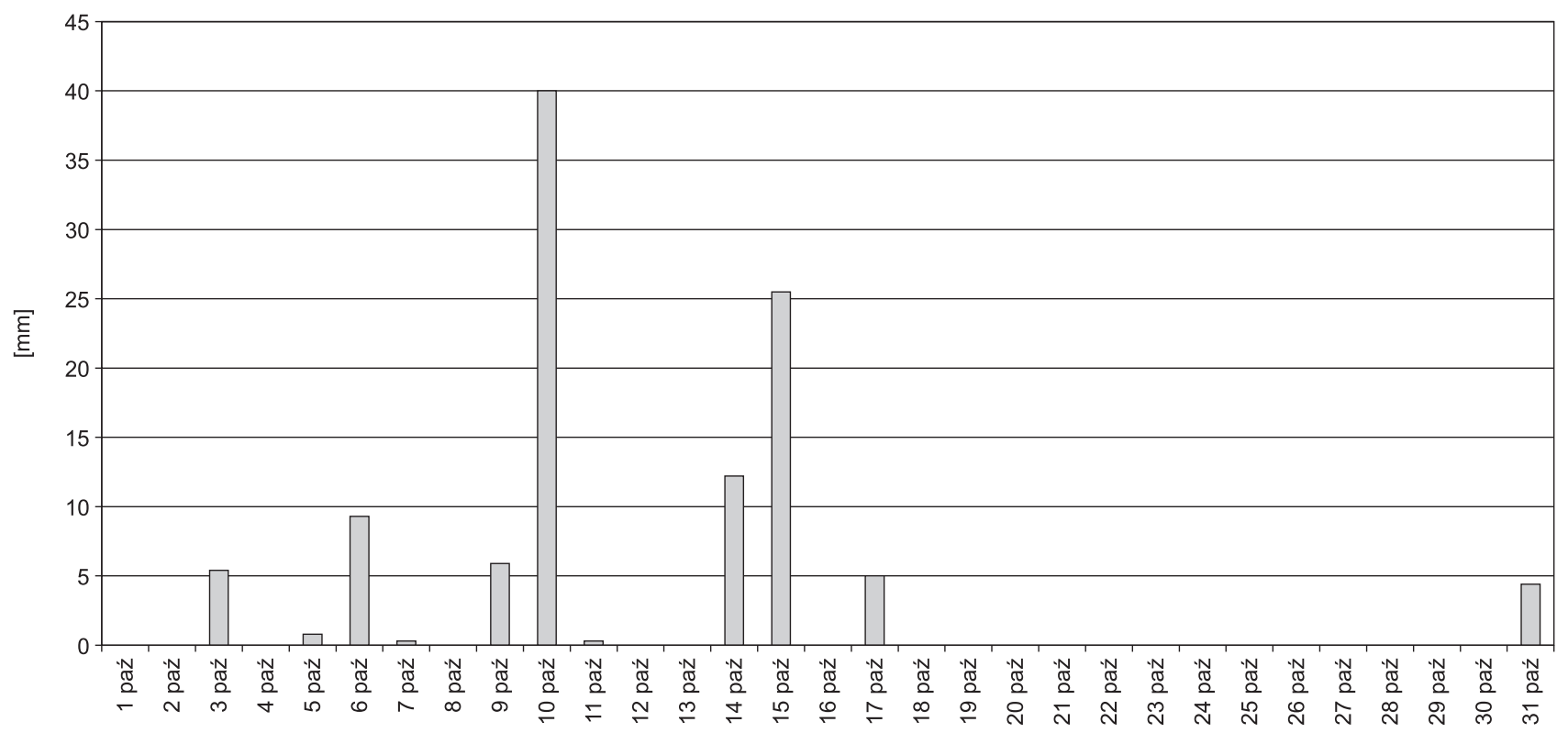

Ryc. 4. Sumy opadów w październiku 1976 roku - stacja Świnoujście (dane IMiGW)

Fig. 4. Precipitation in October 1976 - Świnoujście station (IMiGW)

tym zarejestrowano trzy dni z opadem przekraczającym 10 mm, z tym że w pierwszym dniu (10.10.1976) opad osiągnął $40 \mathrm{~mm}$, natomiast $\mathrm{w}$ dwóch pozostałych (14.10.1976 i 15.10.1976) wyniósł odpowiednio $12,2 \mathrm{~mm}$ i $25,5 \mathrm{~mm}$. Należy zwrócić uwagę, iż dzień przed pierwszym epizodem zarejestrowano opad $6 \mathrm{~mm}$. W efekcie tego suma opadów z dwóch kolejnych dni (09.10.1976 i 10.10.1976) wyniosła $45 \mathrm{~mm}$, natomiast w okresie 14-15.10.1976 opad wyniósł $38 \mathrm{~mm}$. Widoczne są więc dwa zasadnicze okresy, w których suma opadów kształtowała się na poziomie ok. $40 \mathrm{~mm}$. Ważnym okazał się fakt, iż zdarzenia te były przerwane czterodniowym okresem bezdeszczowym, podczas którego nadwyżka dostarczonej wody z pierwszego okresu mogła spokojnie infiltrować w głębsze partie podłoża, przyczyniając się do podniesienia lustra wody podziemnej występującego w strefie kontaktu gliny zwałowej i piasków fluwioglacjalnych. Zwiększona ilość wody w tej strefie prawdopodobnie przyczyniła się do uplastycznienia osadów gliniastych, co spowodowało uruchomienie analizowanego osuwiska IV.

\section{Epizod II - Listopad 1995}

Epizod z listopada 1995 roku dotyczył inicjacji osuwiska I i VI w efekcie silnego spiętrzenia sztormowego. Stanowi on przykład jednego z największych wezbrań sztormowych, jakie zarejestrowano w XX wieku na polskim wybrzeżu. Przypadek ten, jak się okazało, przyczynił się do znacznego przemodelowania rzeźby wolińskich klifów.

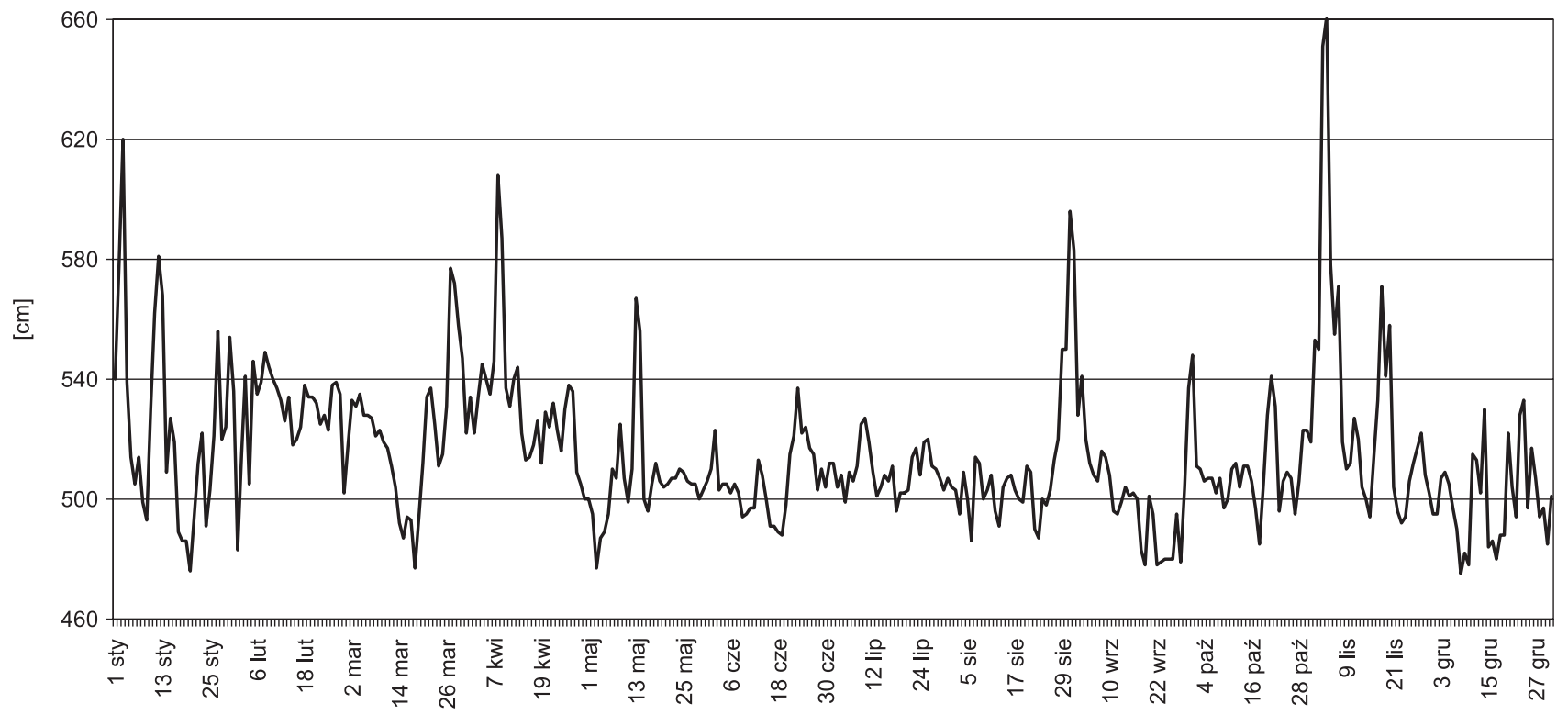

Ryc. 5. Maksymalne poziomy morza w roku 1995 - stacja Świnoujście (dane IMiGW)

Fig. 5. Maximum sea level in 1995 - Świnoujście station (IMiGW) 


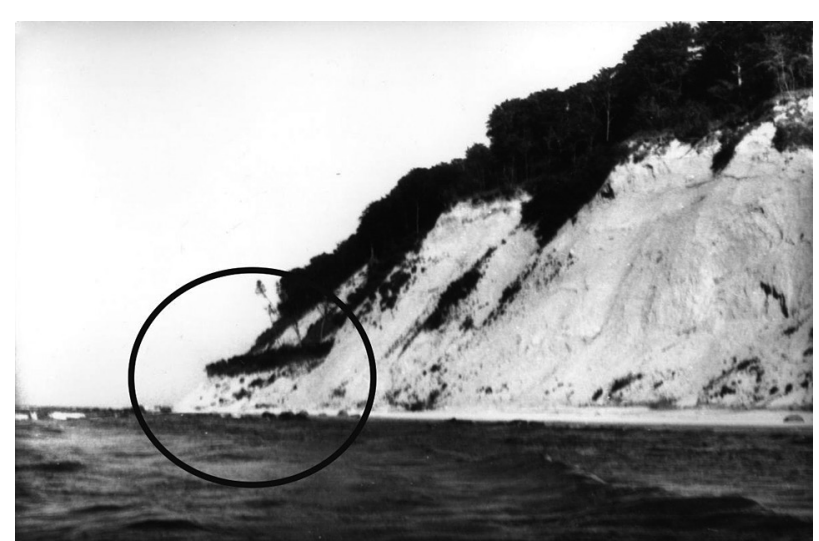

Ryc. 6. Świeżo powstałe osuwisko V - lipiec 1996; fot.: Zb. Zwoliński

Fig. 6. A newly inintiated landslide (V) - July 1996; photo: Zb. Zwoliński

W dniach 3-4 listopada 1995 roku, na zachodnim wybrzeżu południowego Bałtyku, zarejestrowano bardzo duże spiętrzenie sztormowe (ryc. 5). Z początku poziom wody był niewiele wyższy od poziomu średniego, ale już przed południem 3 listopada, sztormowy północny wiatr spowodował szybkie spiętrzanie wody wzdłuż wybrzeża. Poziom morza podnosił się bardzo szybko, a największy przyrost wyniósł ok. $28 \mathrm{~cm} / \mathrm{h}$ na wybrzeżu zachodnim (Sztobryn i in. 2005). Najwyższy poziom morza w dniu 03.11 .1995 wyniósł $651 \mathrm{~cm}$, a dzień później był o $10 \mathrm{~cm}$ wyższy (mareograf Świnoujście). Maksymalna dobowa amplituda poziomu wody zarejestrowana w tym okresie wyniosła $140 \mathrm{~cm}$.

Tak duża dynamika morza wywarła w tym czasie ogromny wpływ na stan rzeźby wolińskich klifów. Przemodelowaniu uległy zarówno klify piaszczyste jak i gliniaste, a abrazja, jaką wówczas zaobserwowano przyjęła największe rozmiary od początku lat 80-tych (Kostrzewski 1997, Kostrzewski, Zwoliński 1998). Doszło wówczas do wykształcenia osuwiska I. Materiały archiwalne z tego okresu dokumentują powstanie osuwiska V (ryc. 6).

\section{Epizod III - Listopad 2001}

Przypadek z listopada 2001 roku dotyczył odświeżenia osuwiska I. Opisywany epizod, podobnie jak poprzedni, również wiązany jest ze wzmożoną dynamiką morza. W okresie tym zaobserwowano cztery wezbrania sztormowe, które nie były już tak znaczące jak te z roku 1995. Maksymalny poziom morza wyniósł wówczas niespełna $598 \mathrm{~cm}$ (09.11.2001), a tydzień później 590 cm (16.11.2001) (ryc. 7). W przypadku wezbrań sztormowych charakter abrazji brzegu, zależy od wielkości i szybkości wzrostu poziomu morza w czasie sztormu (Musielak 1978). W tym przypadku na przełomie 15 i 16 listopada różnica poziomów wody wyniosła aż $164 \mathrm{~cm}$.

Przypadek ten niewątpliwie stanowił ekstremum hydrodynamiczne, które w znaczącym stopniu przyczyniło się do przemodelowania rzeźby wolińskich klifów. Należy również zaznaczyć fakt, iż efektywność geomorfologiczna sztormu z dnia 15-16.11.2001 spotęgowana została uprzątnięciem platformy abrazyjnej przez sztorm z dnia 9.11.2001 roku. Niestety odcinek wybrzeża, na którym znajduje się osuwisko I nie był wówczas objęty badaniami stąd też brak materiałów dokumentujących stan geomorfologiczny tego osuwiska.

\section{Epizod IV - Listopad 2006}

Epizod IV dotyczył odświeżenia osuwiska I. Na początku listopada 2006 roku zaobserwowano wezbranie sztormowe o znacznej energii. Maksymalny poziom morza wyniósł wówczas $616 \mathrm{~cm}$ (01.11.2006), zaś maksymalna amplituda wezbrania sięgnęła $147 \mathrm{~cm}$ (31.10-01.11.2006) (ryc. 8). W okresie tym doszło do silnego przemodelowania podnóża klifu. Występujące $\mathrm{w}$ dolnych partiach klifu formy osypiskowe, zostały całkowicie odprowadzone przez fale

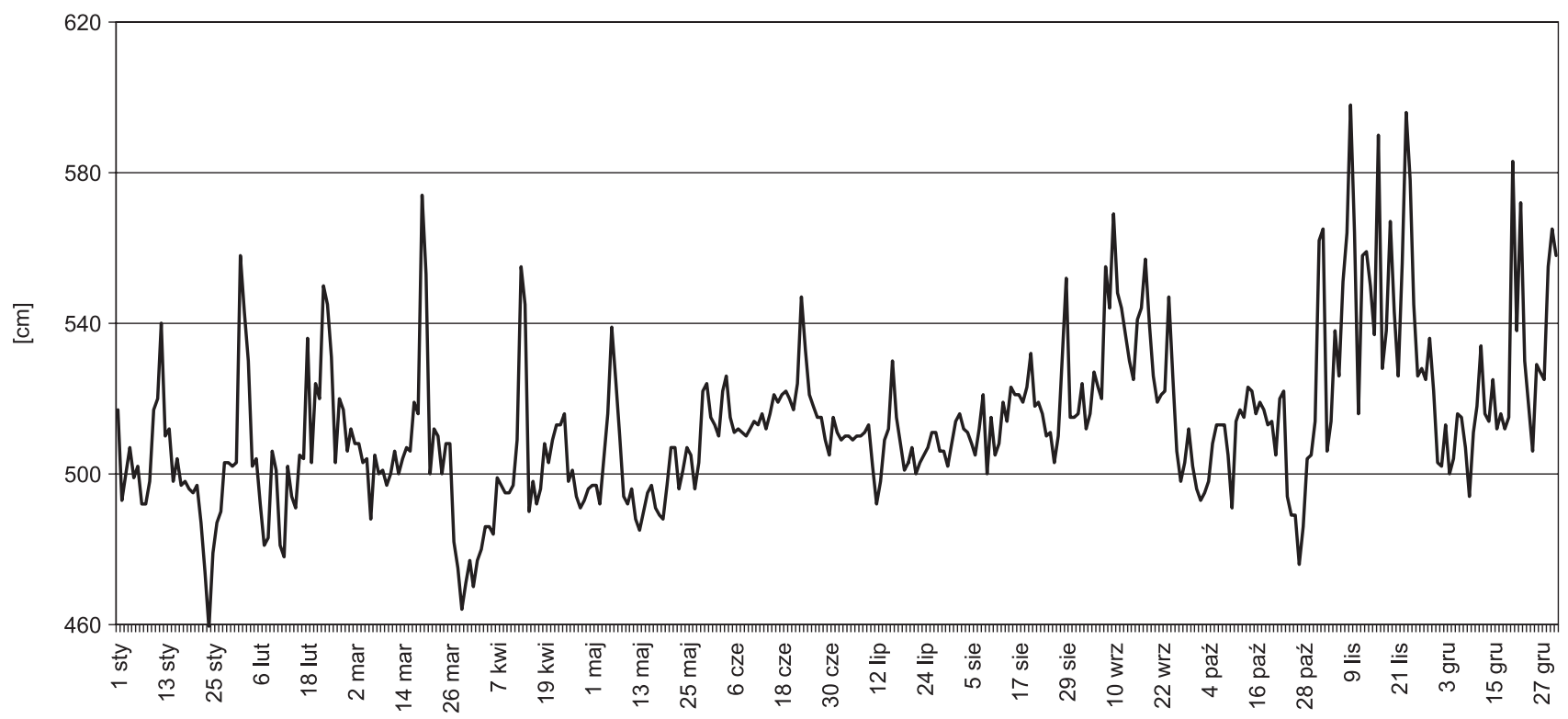

Ryc. 7. Maksymalne poziomy morza w roku 2001 - stacja Świnoujście (dane IMiGW)

Fig. 7. Maximum sea level in 2001 - Świnoujście station (IMiGW) 


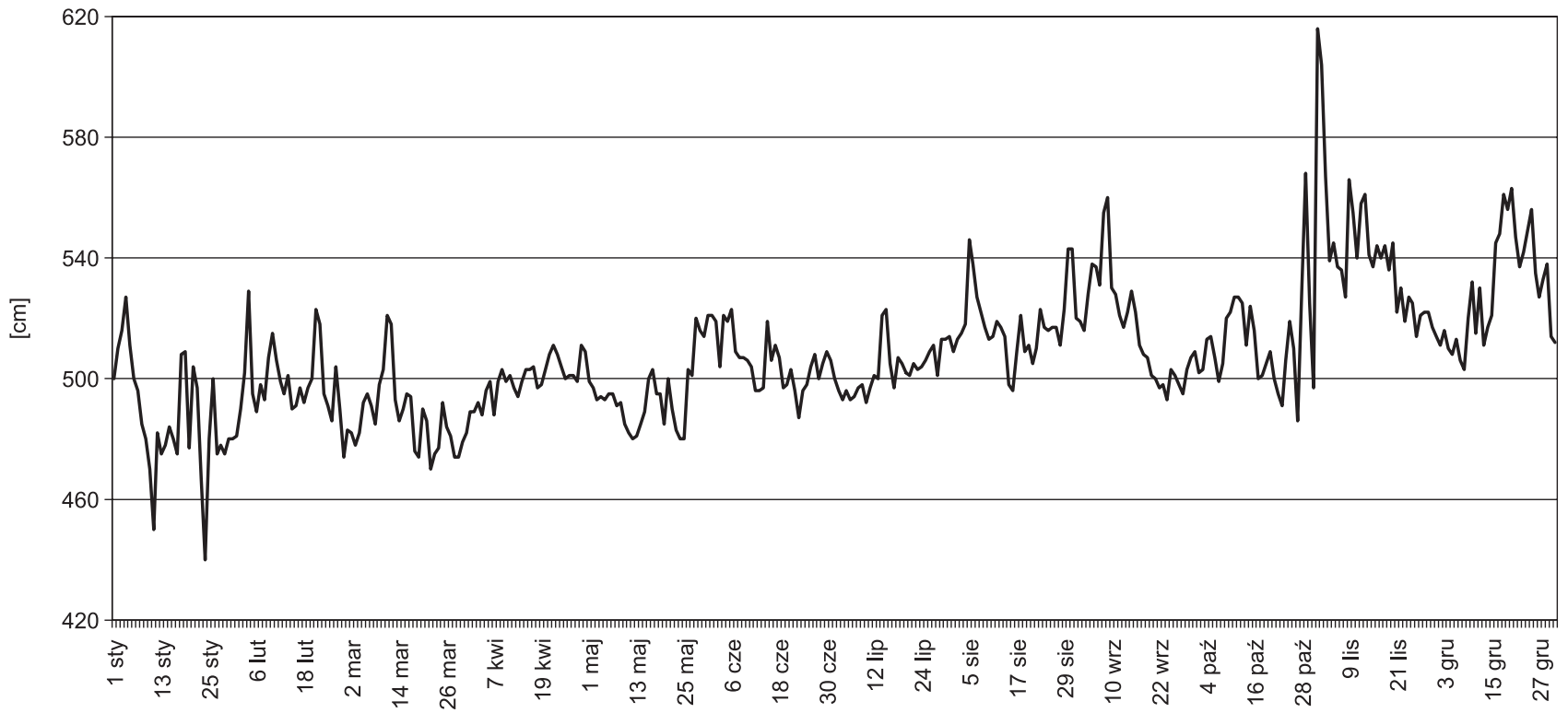

Ryc. 8. Maksymalne poziomy morza w roku 2006 - stacja Świnoujście (dane IMiGW)

Fig. 8. Maximum seal level in 2006 - Świnoujście station (IMiGW)

sztormowe (ryc. 9), co dodatkowo doprowadziło do uruchomienia materiału leżącego w strefie podkoronowej.

Utrata podparcia w strefie podnóża klifu przyczyniła się do destabilizacji zaplecza klifu. W efekcie tego doszło do uruchomienia znajdującego się tam osuwiska i prze- transportowania zasadniczego pakietu materiału na odległość $1 \mathrm{~m}$. W wyniku destabilizacji klifu w strefie koronowej odnotowano także pojawienie szczelin inicjalnych, które dały początek szeregowi mniejszych form osuwiskowych (ryc. 10), (ryc. 11).

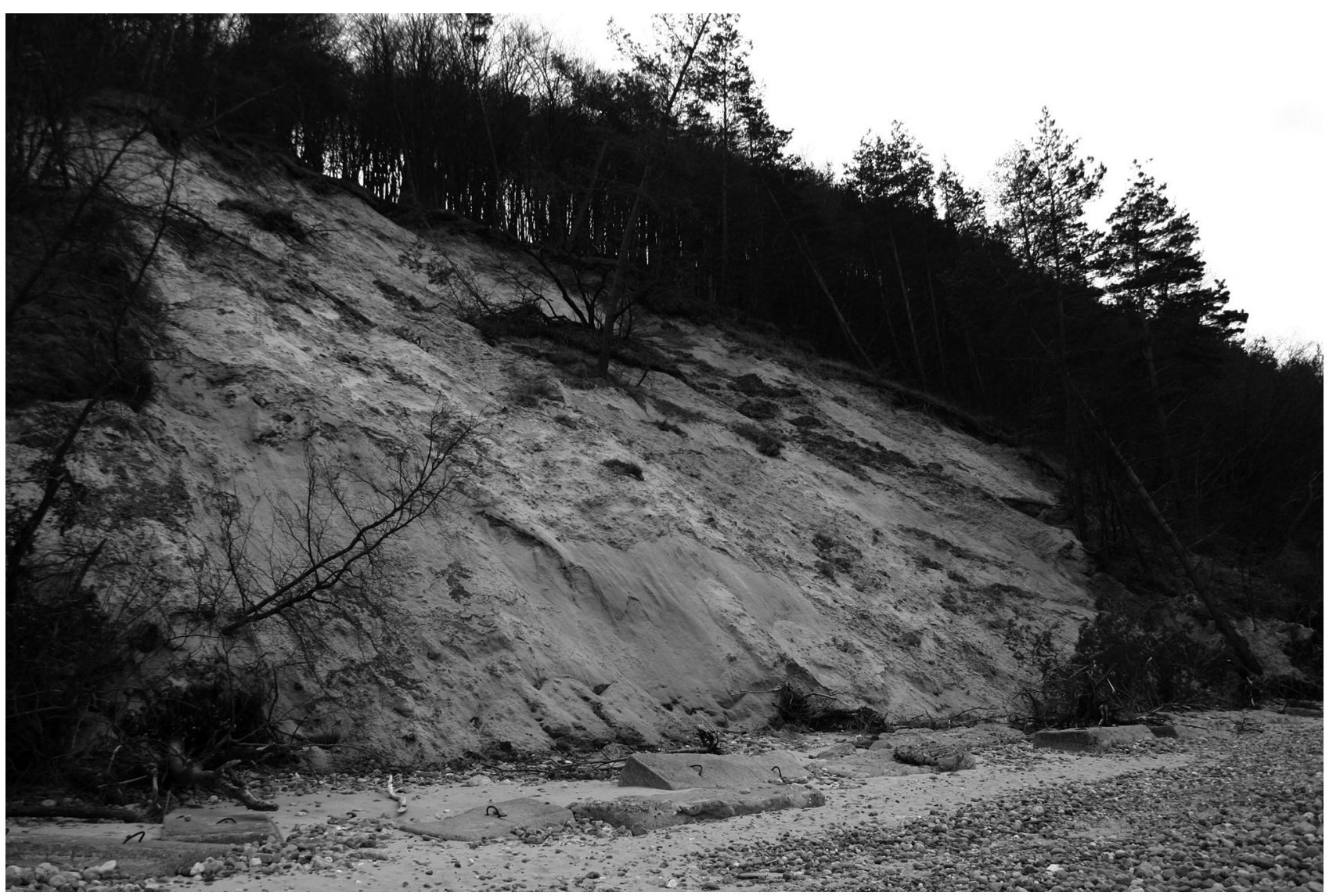

Ryc. 9. Podcięcie abrazyjne, które doprowadziło do uprzątnięcia form osypiskowych zalegających na skłonie klifu i uruchomienia osuwiska I znajdującego się na zapleczu klifu, 16.12.2006

Fig. 9. Abrasive undercut which led to destabilization of cliff slope and initiated a landslide (I) on the back of the cliff, 16.12.2006 


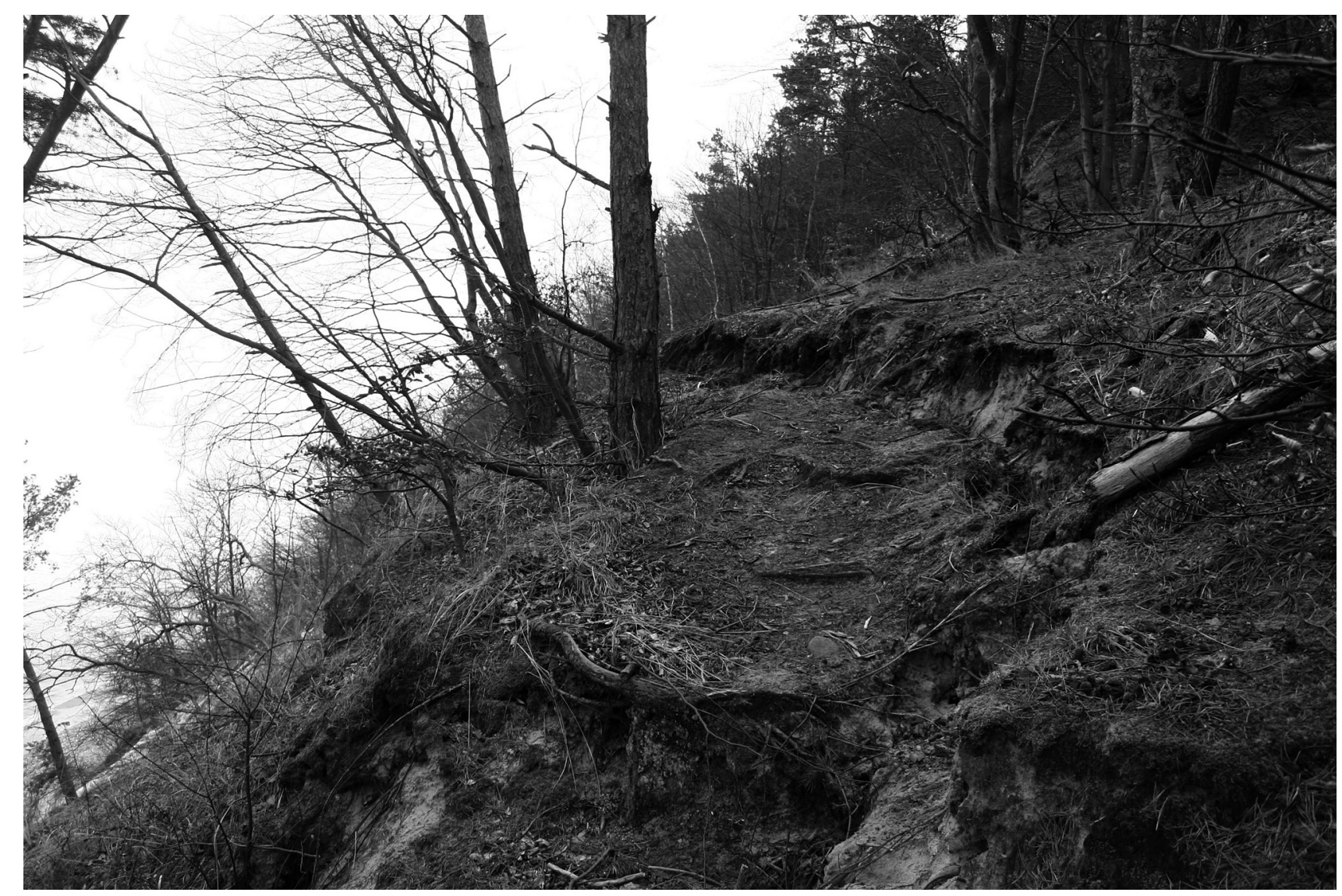

Ryc. 10. Zerwa krawędziowa wykształcona w efekcie destabilizacji strefy krawędziowej klifu (osuwisko I), 16.12.2006

Fig. 10. Edge slump initiated as an effect of cliff edge area destabilization (landslide I), 16.12.2006

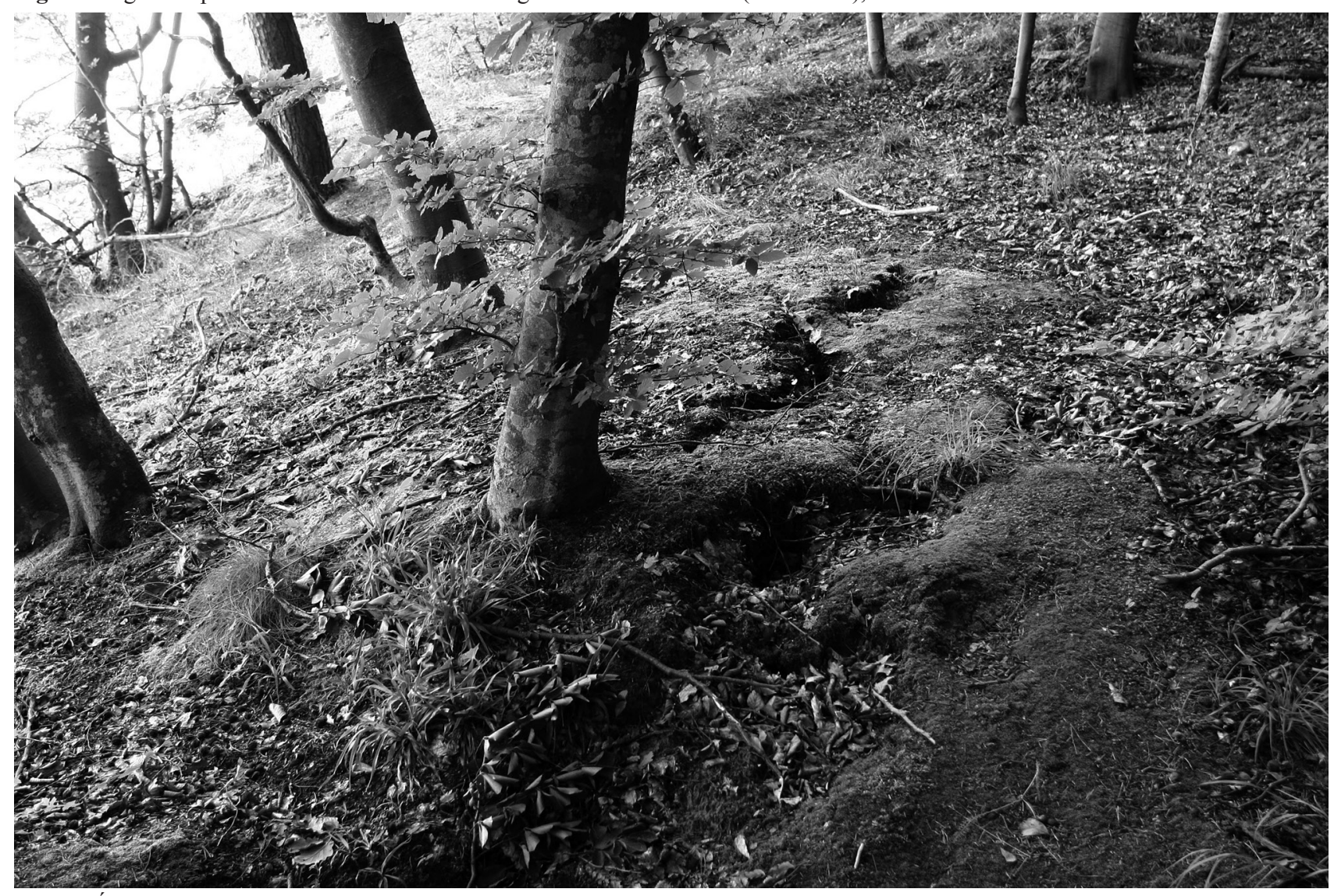

Ryc. 11 Świeża szczelina inicjalna powstała w efekcie destabilizacji zaplecza klifu (osuwisko I), 15.03.2007

Fig. 11. Newly formed dilatation crack as an effect of destabilization of the back of the cliff (landslide I), 15.03.2007 


\section{Epizod V - lipiec 2007}

Główną przyczyną wydzielenia tego epizodu było wystąpienie bardzo dużych opadów atmosferycznych, w skutek czego doszło do zainicjowania pomniejszych procesów osuwiskowych. W lipcu 2007 roku zarejestrowano aż 151 mm opadów. Wartość ta stanowiła $275 \%$ średniej z wielo- lecia dla lipca. Należy przy tym zwrócić uwagę, iż był to najbardziej deszczowy miesiąc od 1973 roku. W okresie tym wystąpiło 20 dni z deszczem (ryc. 12), przy czym opad poniżej $10 \mathrm{~mm}$ wystąpił w $80 \%$ przypadków. Najbardziej wilgotna okazała się pierwsza połowa lipca (112 mm), w trakcie której zaznaczyły się trzy wyraźne

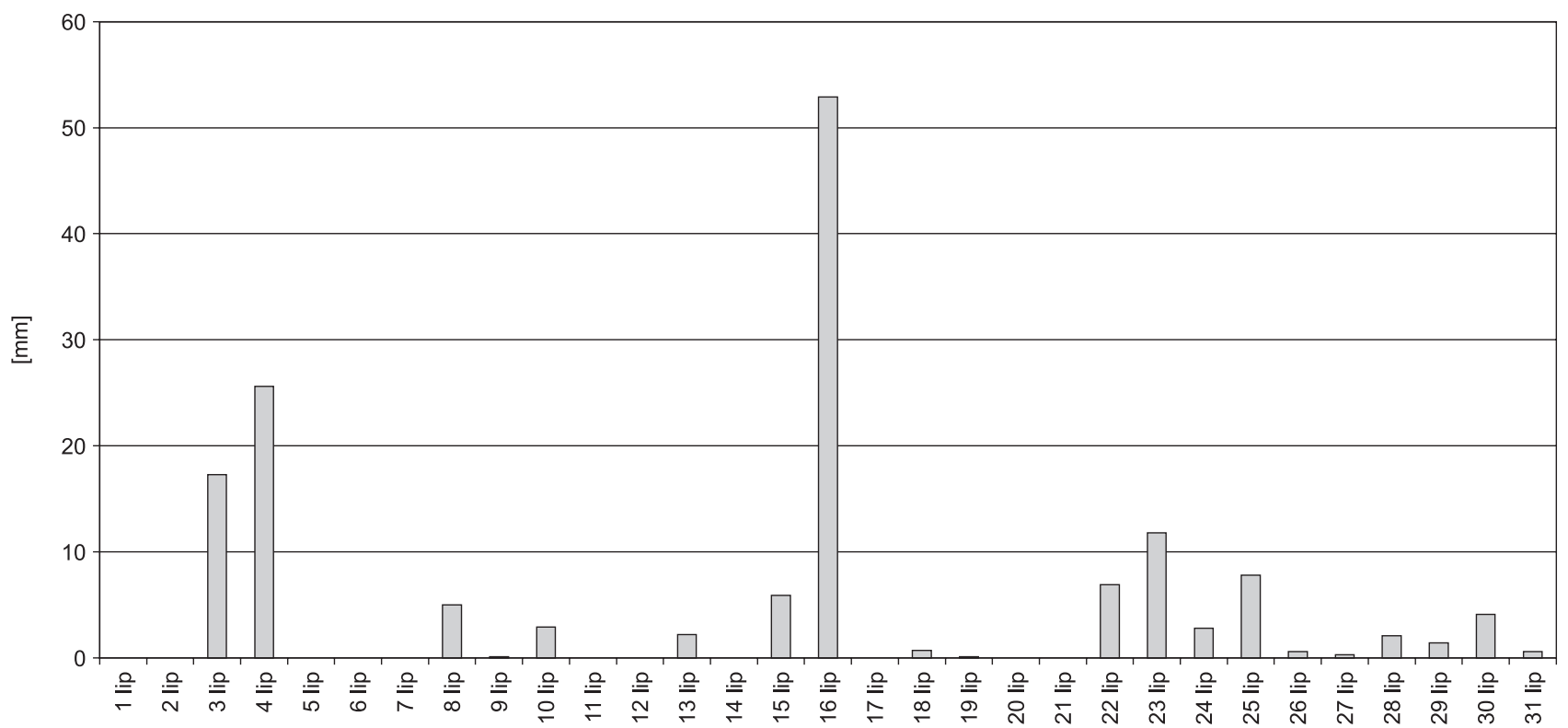

Ryc. 12. Dobowe sumy opadów w lipcu 2007 roku - stacja Świnoujście (dane IMiGW)

Fig. 12. Daily precipitation in July 2007 - Świnoujście station (IMiGW)

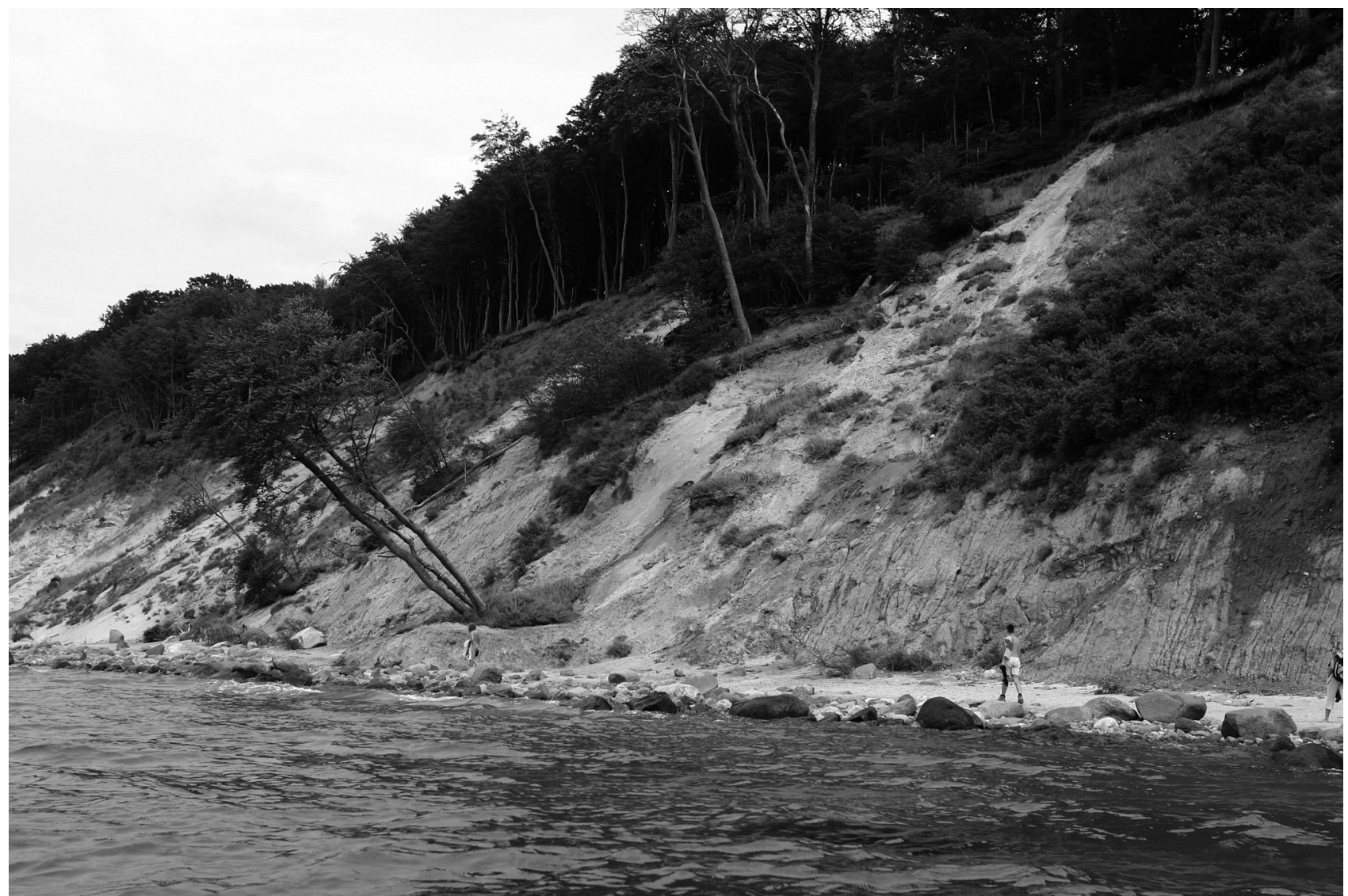

Ryc. 13. Świeżo powstałe osuwisko III po opadzie z 22 lipca 2007 r, 24.07.2007

Fig. 13. Newly formed landslide (III) after rainfall event in July 22, 2007. 24.07.2007 
okresy opadowe. Pierwszy okres wystąpił na przełomie 3 i 4 lipca i był nieustającym, równomiernym opadem charakterystycznym dla przejścia ciepłego frontu atmosferycznego. Tego typu zdarzenia są szczególnie ważne w procesie przygotowawczym stoku. Niezbyt intensywne lecz równomierne opady nie przekraczają zdolności infiltracyjnych podłoża i dlatego nie występuje proces spływu powierzchniowego, który sprawia, iż większość wody opadowej odpływa po stoku. Po wystąpieniu tych opadów na klifach zaobserwowano zwiększoną aktywność wypływów wód podziemnych, które z pozoru nie wywarły znaczącego wpływu na dynamikę procesów stokowych. Po tym epizodzie wystąpił 11-dniowy okres o małej wilgotności. W jego trakcie zanotowano opad wynoszący 16 $\mathrm{mm}$. Cały ładunek wody dostarczony w pierwszym okresie mógł w tym czasie infiltrować w głębsze partie podłoża lub nawet zasilić pierwszy poziom wodonośny. Ostatni epizod reprezentowany jest przez opad z dnia 16 lipca, który miał bardzo duże natężenie. W trakcie jednego dnia zarejestrowano wówczas $53 \mathrm{~mm}$ opadu, który doprowadził do bardzo dużego obciążenia osadów koluwialnych zalegających na stokach klifu.

Najciekawsze przejawy procesów geomorfologicznych wystąpiły wówczas na klifie oddalonym $200 \mathrm{~m}$ na wschód od Wzgórza Gosań. Na obszarze tym doszło do uruchomienia niewielkiego osuwiska (osuwisko III). Forma ta została wykształcona w procesie degradacji systemu dwóch zerw zlokalizowanych w górnej partii klifu. Dynamika tego zdarzenia była na tyle duża, iż osunięty pakiet materiału odzyskał równowagę dopiero na poziomie plaży. Siła, z jaką osuwisko napierało na zalegający poniżej obszar doprowadziła do wyciśnięcia sporej ilości materiału piaszczystego, który na poziomie plaży złożony został pod postacią jęzora osuwiskowego (ryc. 13).

\section{Epizod VI - maj 2008}

Wydarzenie z kwietnia 2008 roku również związane było z wystąpieniem intensywnych opadów atmosferycznych, jednak w tym przypadku efekty morfologiczne były większe niż te, które zaobserwowano w lipcu 2007 roku (Winowski 2008). W analizowanym miesiącu w Świnoujściu wystąpił opad z łączną sumą $98 \mathrm{~mm}$ (był o $10 \mathrm{~mm}$ niższy niż w Białej Górze) i choć była to wartość o wiele niższa od opadów z lipca 2007 roku, to na tle wielolecia stanowiła $258 \%$ opadów rejestrowanych w kwietniu. W okresie tym zarejestrowano 19 dni z opadem (Biała Góra - 13 dni) (ryc. 14). W przypadku Świnoujścia 15 dni z opadem wystąpiło $\mathrm{w}$ pierwszej połowie miesiąca, natomiast w Białej Górze w tym czasie padało przez 11 dni. Podczas dwóch pierwszych tygodni kwietnia zarejestrowano opad przekraczający $90 \mathrm{~mm}$ (podobnie w obydwu przypadkach), przy czym w Świnoujściu 63\% tych opadów wystąpiło podczas dwóch dni (7-8 kwietnia - $57 \mathrm{~mm}$ ), natomiast w Białej Górze w tym samym czasie zarejestrowano opad $65 \mathrm{~mm}$ stanowiący $71 \%$ opadów pierwszej połowy kwietnia.

Po tym zdarzeniu spadł śnieg, który utworzył zwartą pokrywę. Wskutek utrzymywania się dodatniej temperatury uległ on sukcesywnemu wytapianiu. Tak duża dostawa wody do podłoża budującego zbocza klifów, przyczyniła się do uruchomienia szeregu procesów osuwiskowych i spływowych. Zwiększona infiltracja zachodziła tylko na odcinkach piaszczystych i piaszczysto-gliniastych, zaś na klifach gliniastych dominował spływ powierzchniowy. W przypadku zboczy zsuwiskowo-spływowych na skutek wzrostu wilgotności i zmiany konsystencji osadów spoistych, nastąpiło ścięcie powierzchniowych partii zboczy, które doprowadziło do utworzenia się szeregu osuwisk translacyjnych i rotacyjnych.

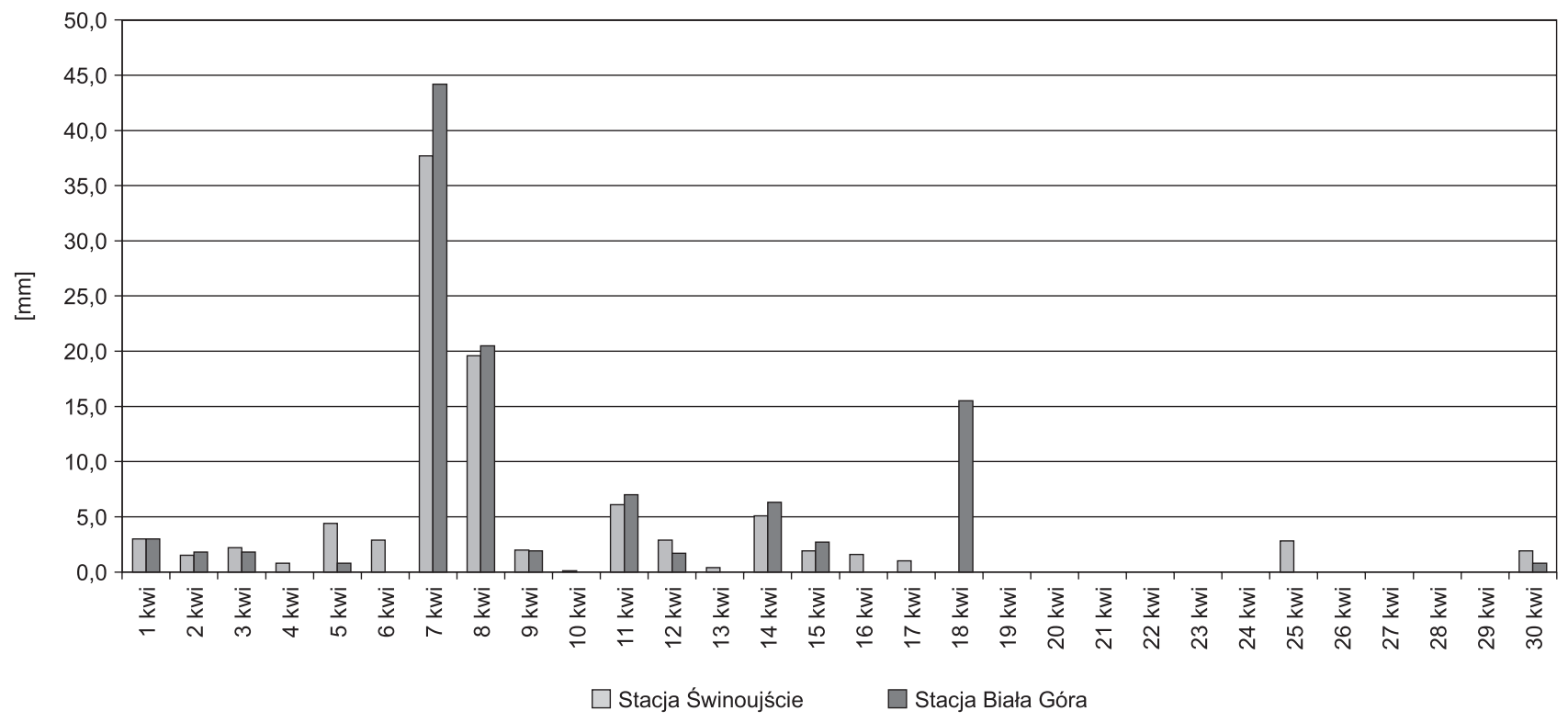

Ryc. 14. Sumy opadów w kwietniu 2008 roku - stacja Świnoujście i Biała Góra (dane IMiGW i Stacja Monitoringu Środowiska Przyrodniczego)

Fig. 14. Precipitation in April 2008 - Świnoujście and Biała Góra stations (IMiGW and Station of Natural Environment Monitoring) 


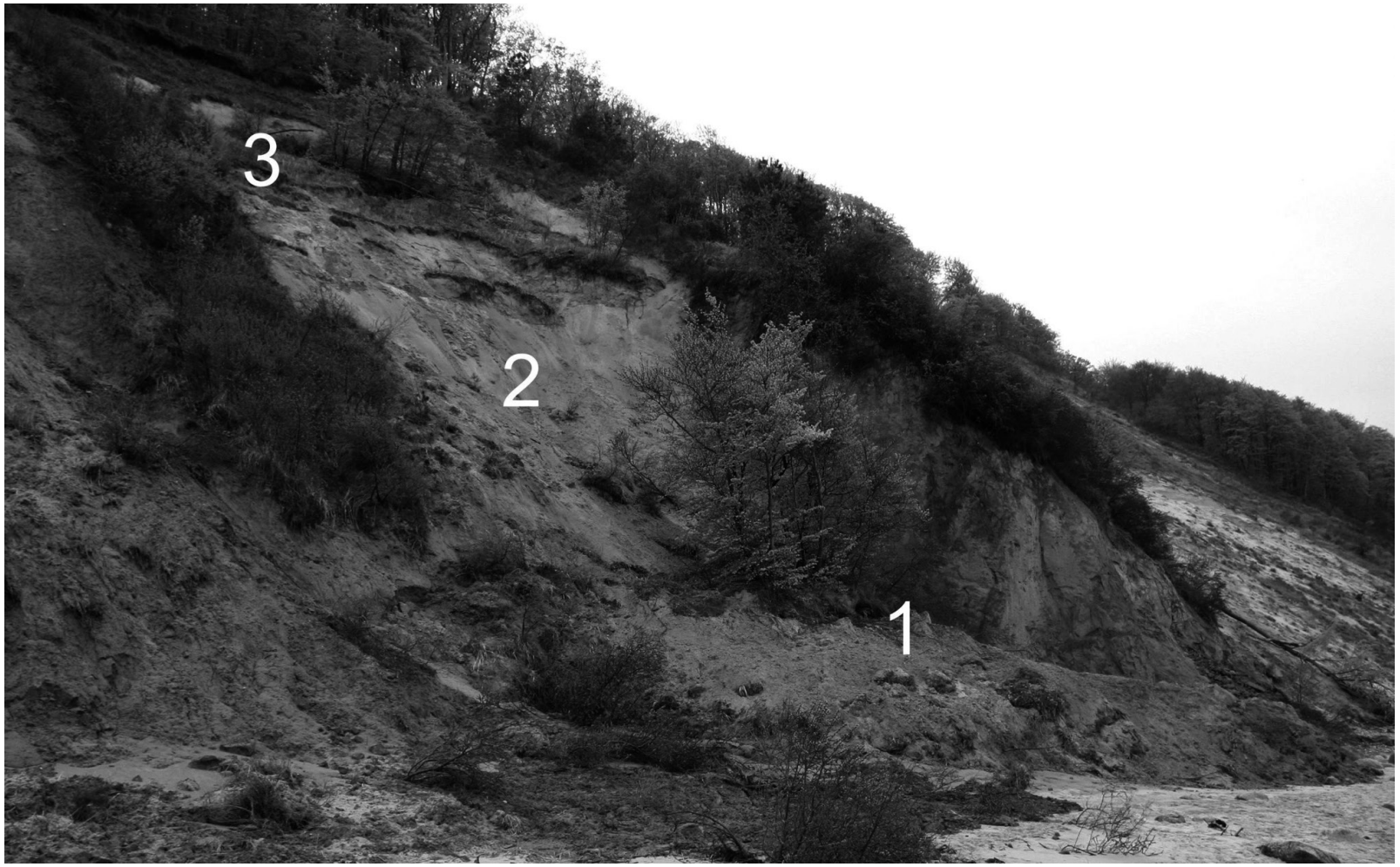

Ryc. 15. Powstanie osuwiska w środkowej partii klifu przyczyniło się do wykształcenia zerwy w strefie podkoronowej po opadach z kwietnia 2008 roku (osuwisko II),01.05.2008

1 - jęzor osuwiskowy, 2 - powierzchnia poślizgu osuwiska, 3 - zerwa

Fig. 15. Initiation of landslide in the central part of the cliff contributed to initiation of the slump in the top of the cliff after the rainfall episode in April 2008, (landslide II), 01.05.2008

1 - landslide tongue, 2 - landslide surface, 3 - slump

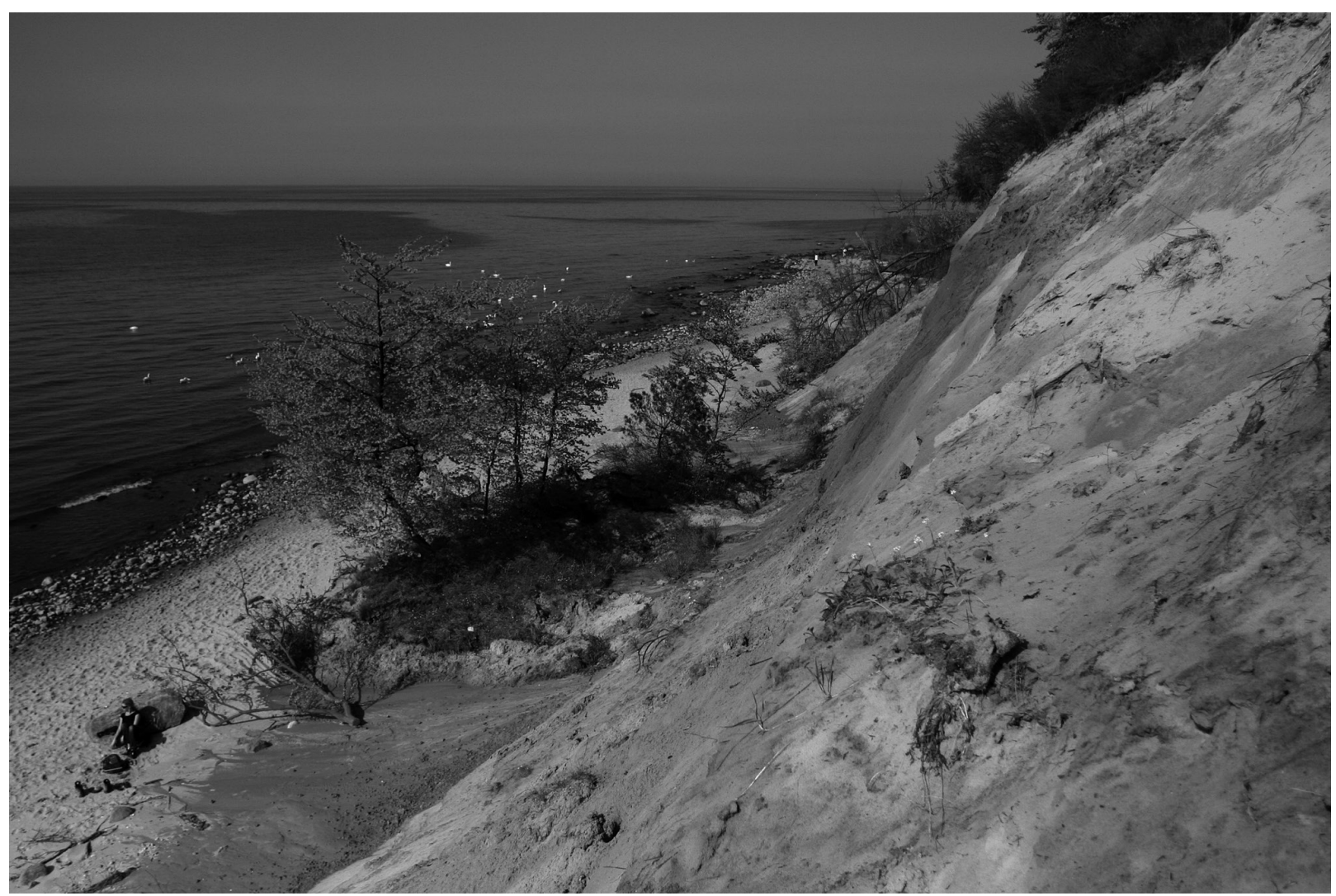

Ryc. 16. Zerwa krawędziowa zdeponowana u podnóża podciosu abrazyjnego (osuwisko IV), 01.05 .2008

Fig. 16. Edge slump deposited at the base of abrasive undercut (landslide IV), 01.05.2008 


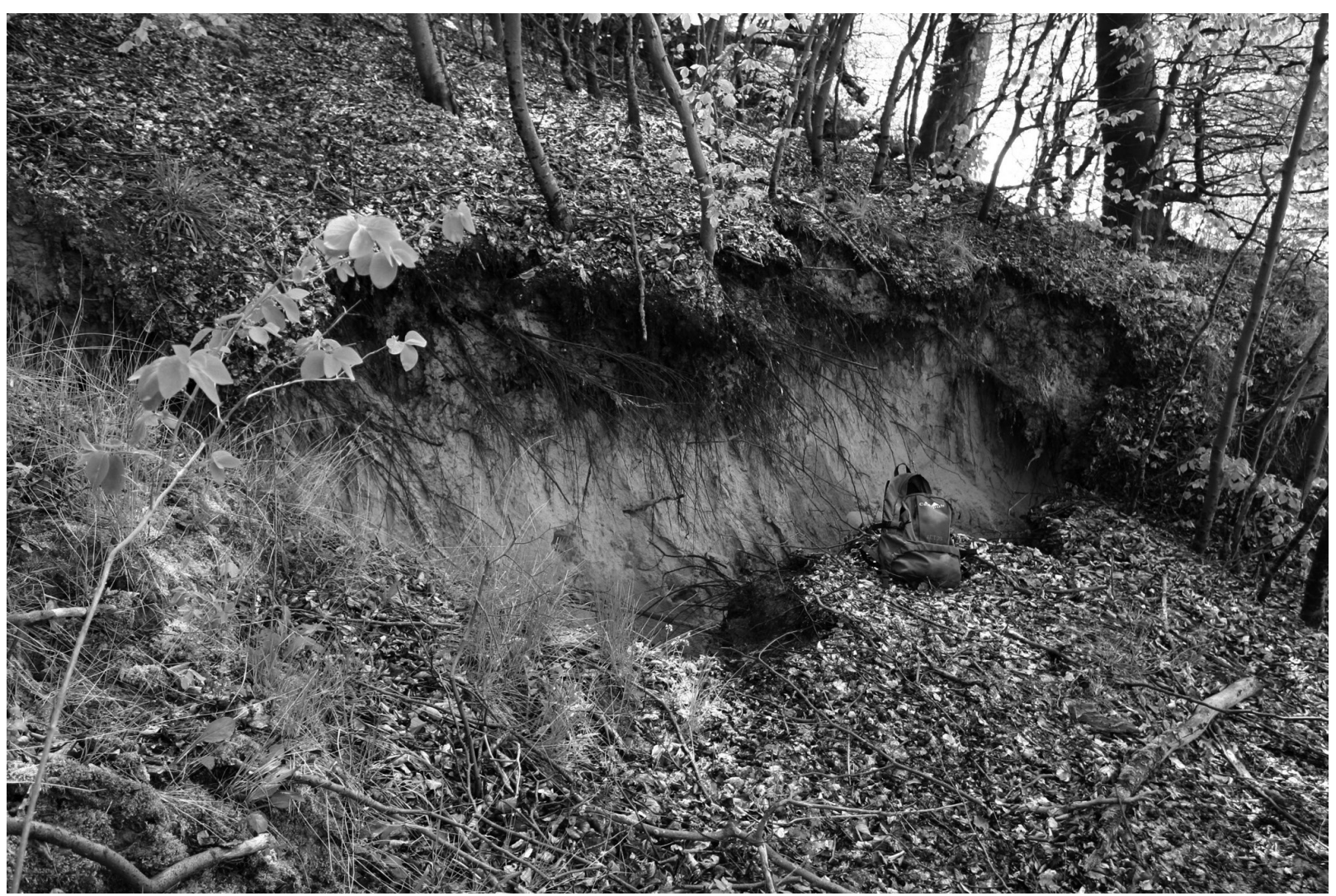

Ryc. 17. Pęknięcie, które podzieliło koluwium na dwa mniejsze stopnie (osuwisko IV), 01.05.2008

Fig. 17. Dilatation crack which divided coluvium block on two smaller parts (landslide IV), 01.05.2008

Taka sytuacja wystąiła w przypadku osuwiska II (ryc. 15). W tym przypadku przepojony wodą grunt zsunął się w dół stoku tworząc na jego przedpolu rozległy jęzor osuwiskowy. Utrata podparcia w środkowej części klifu wpłynęła na destabilizację partii podkoronowej. W efekcie tego wykształciła się płytka zerwa, której miąższość maksymalnie sięgała $1,5 \mathrm{~m}$ (Winowski 2008).

Do podobnej sytuacji doszło również na klifie położonym w bezpośrednim sąsiedztwie Wzgórza Gosań. Zwiększenie wilgotności gruntu przyczyniło się do odświeżenia i częściowego zdegradowania zerwy wystę-

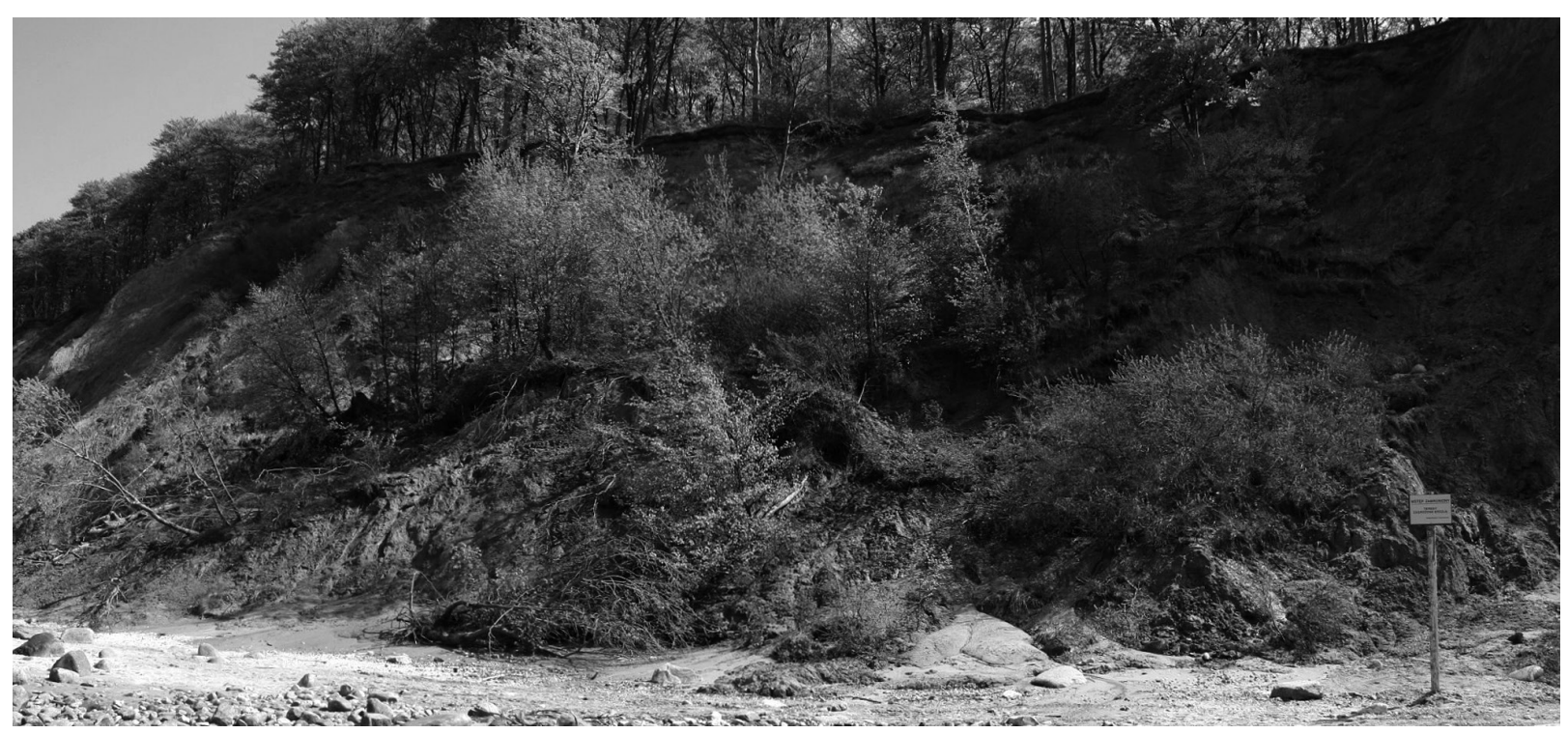

Ryc. 18. Strefa czołowa osuwiska silnie przemodelowana przez erozyjną działalność wód gruntowych i powierzchniowych (osuwisko V), 01.05.2008

Fig. 18. Front area of landslide strongly transformed by surface water and groundwater erosive activity (landslide IV), 01.05 .2008 
pującej na podciosie abrazyjnym. Pierwotnie w strefie krawędziowej zerwy, którą stanowi krawędź podciosu abrazyjnego wykształcona została mniejsza forma osuwiskowa, która w postaci nienaruszonej zsunęła się po podciosie abrazyjnym do poziomu plaży, tworząc koluwium o powierzchni ok. $110 \mathrm{~m}^{2}$ i objętości ok. $180 \mathrm{~m}^{3}$ (ryc. 16). W efekcie ubytku z części krawędziowej tak dużej ilości materiału, destabilizacji uległa zasadnicza część zerwy, która osunęła się w dół klifu na odległość 1-1,5 m. Uaktywnienie tego osuwiska przyczyniło się do jego częściowej degradacji. W środkowej części powstało pęknięcie, które podzieliło zerwę na dwa mniejsze stopnie (ryc. 17, Winowski 2008).

Zarejestrowane opady atmosferyczne przyczyniły się również do przemodelowania osuwiska (V). W tym przypadku zaobserwowano dość znaczną degradację koluwium. Z uwagi na to, iż omawiana forma zbudowana jest głównie z osadów spoistych, wystąpienie okresu szczególnie wilgotnego miało dość znaczący wpływ na charakter zachodzących procesów. Po wystąpieniu opadów doszło do znacznego rozluźnienia materiałów spoistych, które w obrębie czoła osuwiska podlegały procesom spływowym. Spływająca woda rzeźbiła w podłożu rozmaite formy erozji linijnej i powierzchniowej, a zerodowany materiał został wyniesiony na przedpole klifu i zdeponowany w postaci licznych stożków napływowych i pokryw spływowych. Powszechne w strefie krawędziowej procesy sufozji doprowadziły do wykształcenia niewielkich zerw, które po krótkim czasie uległy szybkiej degradacji (ryc. 18).

\section{Dyskusja}

W latach 1973-2009 udokumentowano sześć epizodów, które wywarły znaczący wpływ na rozwój procesów osuwiskowych w obrębie wybrzeża klifowego wyspy Wolin. Przypadki te reprezentowane były przez silne wezbrania sztormowe oraz intensywne opady atmosferyczne. W efekcie tych zdarzeń dochodziło do zainicjowania, odświeżania oraz degradowania osuwisk. Procesy geomorfologiczne, które w ich efekcie wystąpiły miały dużą dynamikę, a im większe było natężenie czynnika morfotwórczego, tym wyraźniejsze efekty morfologiczne można było zaobserwować. Zaprezentowane przypadki dowodzą, iż procesy morfogenetyczne o wysokim natężeniu pełnią istotną rolę w funkcjonowaniu nie tylko osuwisk, ale i całego systemu morfogenetycznego wybrzeża klifowego.

Na podstawie analizy przedstawionych epizodów wydzielić można wartości progowe, których przekroczenie skutkuje uruchomieniem procesu osuwiskowego. Osuwiska o genezie sztormowej powstają przeważnie poprzez abrazyjne podcięcie podnóża klifu. Proces ten doprowadza do zwiększenia nachylenia stoku, przez co w jego obrębie siła odrywająca zaczyna przewyższać siłę stabilizującą materiału budującego stok. Zachwianie stabilności klifu skutkuje ścięciem osadów i przemieszczaniem ich
Tabela 1. Katalog ekstremalnych zdarzeń hydrometeorologicznych dla wybrzeża klifowego wyspy Wolin wyznaczony w oparciu o wydzielone wartości progowe dynamiki osuwisk (dane IMiGW)

Table 1. Catalogue of extreme hydrological and meteorological events for Wolin Island cliff coast determined on the base of selected threshold values of landslide activity (IMiGW)

\begin{tabular}{|c|c|c|}
\hline \multicolumn{3}{|c|}{ Wezbrania sztormowe } \\
\hline Data & $\begin{array}{l}\text { Maksymalny } \\
\text { poziom morza }\end{array}$ & $\begin{array}{l}\text { Maksymalna dobowa } \\
\text { amplituda wezbrania } \\
{[\mathrm{cm}]}\end{array}$ \\
\hline 20.11 .1973 & 607 & 147 \\
\hline 10.12 .1983 & 598 & 148 \\
\hline 29.11 .1988 & 609 & 146 \\
\hline 21.02.1993 & 641 & 148 \\
\hline 03.11 .1995 & 651 & 140 \\
\hline 16.11.2001 & 590 & 164 \\
\hline 06.12 .2003 & 604 & 145 \\
\hline 01.11 .2006 & 616 & 147 \\
\hline 27.01.2007 & 601 & 151 \\
\hline \multicolumn{3}{|c|}{ Opady atmosferyczne } \\
\hline Okres opadowy & $\begin{array}{l}\text { Suma opadów } \\
\text { w okresie opa- } \\
\text { dowym }\end{array}$ & $\begin{array}{l}\text { Najwyższa suma opa- } \\
\text { dów dwóch kolejnych } \\
\text { dni w okresie opado- } \\
\text { wym } \\
\text { [mm] }\end{array}$ \\
\hline $03-17.10 .1976$ & 104 & 45 \\
\hline $18.06-02.07 .1980$ & 121 & 70 \\
\hline $07-23.09 .1987$ & 121 & 63 \\
\hline $23.08-06.09 .1992$ & 94 & 49 \\
\hline $30.06-14.07 .2007$ & 114 & 53 \\
\hline 01-15.04.2008 & 91 & 57 \\
\hline
\end{tabular}

po stoku w postaci osuwiska aż do momentu odzyskania względnej równowagi dynamicznej. Przeprowadzone analizy warunków mareograficznych wykazały, iż osuwiska powstawały zawsze gdy poziom morza przekroczył $590 \mathrm{~cm}$, przy czym maksymalna amplituda dobowa wezbrania nigdy nie była niższa niż $140 \mathrm{~cm}$.

Okres przygotowawczy odgrywa również bardzo ważną rolę w kształtowaniu osuwisk o genezie opadowej. Okres taki gwarantuje dostawę pewnej ilości wody do ośrodka gruntowego, która w odpowiedni sposób zmienia jego właściwości fizyczne, jednak jej ilościowe określenie nastręcza wiele trudności, które wynikają z lokalnego charakteru uwarunkowań litologiczno-strukturalnych podłoża. W tej sytuacji ważny jest charakter opadu oraz zdolności infiltracyjne podłoża. Optymalnym scenariuszem dla powstania osuwiska jest piętnastodniowy opad o sumie przekraczającej $90 \mathrm{~mm}$, przy czym w dwóch kolejnych dniach tego okresu powinien wystąpić opad przekraczający 40 mm, który w znaczący sposób dociążył by podłoże zwiększając tym samym jego podatność na osunięcie.

Należy zauważyć, iż inicjacja procesu osuwiskowego warunkowana jest także wieloma innymi czynnikami, które najczęściej mają charakter lokalny (morfologia, litologia, struktura osadów czy hydrogeologia). Klify o budowie piaszczysto gliniastej, z wyraźnie zaznaczającym 
się poziomem wód gruntowych i wykształconym podciosem abrazyjnym chroniącym górne partie klifu przed niszczącą działalnością fal morskich, wykazują większą podatność na powstawanie osuwisk o genezie opadowej. Osuwiska o genezie sztormowej najczęściej będą powstawały na klifach o budowie piaszczystej, bez wyraźnie wykształconego podciosu abrazyjnego, co będzie sprzyjało abrazyjnemu oddziaływaniu fali przyboju na podnóże klifu.

Należy więc stwierdzić, iż stosowanie w praktyce wydzielonych wartości progowych staje się skuteczne dopiero wtedy gdy pod uwagę weźmie się lokalne uwarunkowania występowania procesów osuwiskowych. Mając na uwadze ustalone wartości progowe przedstawiony został katalog ekstremalnych zdarzeń hydrometeorologicznych (1973-2009), które potencjalnie mogły wywrzeć wpływ na funkcjonowanie osuwisk na wybrzeżu klifowym wyspy Wolin (tab. 1).

W okresie 1973-2009 wystąpiło dziewięć epizodów sztormowych oraz sześć epizodów opadowych, które mogły przyczynić się do uruchomienia procesów osuwiskowych w obrębie wolińskich klifów. Ekstremalne zdarzenia sztormowe występowały średnio co 3 lata i 8 miesięcy, zaś zdarzenia opadowe co 5 lat i 3 miesiące. W sumie na przestrzeni ostatnich 37 lat (1973-2009) zaobserwowano 15 ekstremalnych zdarzeń hydrometeorologicznych. Należy zwrócić uwagę, iż najmniejszą frekwencję tych epizodów zaobserwowano w latach siedemdziesiątych (2), zaś największą w trakcie ostatnich 9 lat analizowanego okresu (6).

\section{Podsumowanie}

Przeprowadzone badania wykazały, iż zdarzenia hydrometeorologiczne o wysokim potencjale morfogenetycznym wywierają bardzo duży wpływ na funkcjonowanie osuwisk klifowych. Analizy pozyskanych materiałów pozwoliły zidentyfikować 6 epizodów (październik 1973, listopad 1995, listopad 2001, listopad 2006, czerwiec - lipiec 2007, kwiecień 2008), w trakcie których obserwowane osuwiska poddawane były inicjacji lub odświeżaniu.

Największe przeobrażenia zboczy klifowych zachodzą niewątpliwie w trakcie wezbrań sztormowych. W efekcie wysokiego podniesienia poziomu wody oraz znacznego falowania zachodzi proces abrazji podnóża klifu, co z kolei przyczynia się do zachwiania równowagi geodynamicznej całego zbocza klifu. Utrata stabilności górnych partii klifu skutkuje najczęściej powstaniem osuwisk o różnych rozmiarach, co czasami może się wiązać z zaistnieniem zagrożenia dla ludności oraz infrastruktury zlokalizowanej w bliskiej odległości od krawędzi klifu. Przeprowadzone analizy poziomów morza wykazały, iż najbardziej optymalne warunki do wykształcenia osuwiska klifowego zachodzą wówczas gdy poziom morza przekracza $590 \mathrm{~cm}$, zaś dobowa amplituda tego zjawiska nie może być mniejsza niż $140 \mathrm{~cm}$. Analiza warunków maregoraficznych z ostatnich 37 lat pozwoliła zidentyfi- kować 9 epizodów, w trakcie których poziom morza osiągnął lub przekroczył wartości progowe.

Kolejnym ważnym czynnikiem wywołującym procesy osuwiskowe na wolińskich klifach są opady atmosferyczne. W trakcie ulewnych opadów woda dostarczana do ośrodka gruntowego staje się katalizatorem ruchów masowych. Proces ten odbywa się na drodze dociążania stoku oraz zmiany cech fizycznych gruntu. Nagła zmiana wilgotności oraz konsystencji gruntu wyraźnie zwiększa podatność zbocza na osunięcie. W przypadku badanych klifów sytuacja taka może zaistnieć wówczas gdy w okresie 15 dni obserwujemy opad przekraczający $90 \mathrm{~mm}$. Ważnym jest również fakt, iż w trakcie tego okresu muszą wystąpić dwa dni z opadem przekraczającym $40 \mathrm{~mm}$. W sumie w okresie 1973-2009 sytuacji, które spełniły przedstawione założenia zarejestrowano 6 . Na przestrzeni ostatnich czterech dekad wystąpiło 15 zdarzeń hydrometeorologicznych ( 9 wezbrań sztormowych, 6 ulewnych opadów atmosferycznych), których parametry spełniały kryteria zaproponowanych wartości progowych.

\section{Podziękowania}

Pragnę podziękować dyrekcji Wolińskiego Parku Narodowego za umożliwienie przeprowadzenia badań na terenie Parku. Podziękowania kieruję także w stronę Instytutu Meteorologii i Gospodarki Wodnej za udostępnienie danych meteorologicznych i mareograficznych za lata 1973-2009 ze Stacji Świnoujście. Szczególne podziękowania kieruję również w stronę Prof. nzw. dr hab. Zbigniewa Zwolińskiego i Prof. zw. dr hab. Andrzeja Kostrzewskiego za udostępnienie dokumentacji fotograficznej wolińskich klifów z lat 1981-2004, bez której przeprowadzenie zaprezentowanych analiz stałoby się niemożliwe. Pragnę podziękować również dr Agacie Budchwał za pomoc w przeprowadzeniu analiz dendrochronologicznych. Wyniki tych badań stanowiły bardzo ważne źródło informacji dla rozwikłania problemu założonego badawczego. Dziękuję także anonimowym recenzentom za cenne rady i wskazówki, które pomogły mi $\mathrm{w}$ udoskonaleniu niniejszej pracy.

\section{Literatura}

Bielec-Bakowska Z., Lupikasza E., 2009. Long-term precipitation variability on thunderstorm days in Poland (1951-2000). Atmospheric Research 93, 506-515. http://dx.doi.org/10.1016/j.atmosres.2008.09.018

Buchwał A., Winowski M., 2009. Reconstructing temporal patterns of rotational landslides activity using dendrogeomorphological approach (Wolin Island). Quaestiones Geographicae 28(A/2): 5-14.

Dreier N., Schlamkow C., Frohle P., Salecker D., 2013. Changes of $21^{\text {st }}$ century's average and extreme wave conditions at the German Baltic Sea coast due to global climate change. Journal of Coastal Research Special Issue 65: 1921-1926.

Gärtner H., 2003. Holzanatomische Analyse diagnostischer Merkmale einer Freilegungsreaktion in Jahrringen von Koniferenwurzeln zur Rekonstruktion geomorphologischer Prozesse. Dissertationes Botanicae 378: 1-118. 
IPCC, 2007. Climate change. The physical science basis. Contribution of Working Group I to the Fourth Assessment Report of the Intergovernmental Panel in Climate Change, Cambridge University Press, Cambridge.

Jania J., Zwoliński Zb., 2011. Ekstremalne zdarzenia meteorologiczne, hydrologiczne i geomorfologiczne w Polsce. W: Zb.Zwoliński (red.), Globalne zmiany klimatu i ich implikacje dla rzeźby Polski, Landform Analysis 15: 51-64.

Kostrzewski A., 1997. Geomorfologiczne skutki gwałtownego sztormu na wybrzeżu klifowym Wyspy Wolin (jesień 1995). [W:] A. Kostrzewski, B. Jakuczun (red.), Ochrona środowiska przyrodniczego WPN. Woliński Park Narodowy, Międzyzdroje: 55-56.

Kostrzewski, A., Zwoliński, Zb., 1998. Wpływ sztormów na rzeźbę wybrzeża klifowego wyspy Wolin. The influence of storms on relief of the cliff coasts of Wolin Island. [W:] K. Pękala (red.), Główne kierunki badań geomorfologicznych w Polsce. Stan aktualny i perspektywy. IV Zjazd Geomorfologów Polskich. UMCS, Lublin: 129-132.

Kostrzewski A., Zwoliński Zb., Winowski M., Tylkowski J., Samołyk M., 2015. Cliff top recession rate and cliff hazards for the sea coast of Wolin Island (Southern Baltic). Baltica 28(2): 109-120. DOI: 10.5200/baltica.2015.28.10.
Musielak S., 1978. Procesy litodynamiczne w strefie przyboju. KBM PAN. Ossolineum: Oceanologia 8: 1-56.

Schweingruber F.H., 1978. Mikroskopische Holzanatomie. Swiss Federal Institute of Forestry Research, Birmensdorf: 215.

Schweingruber F.H., 2007. Wood structure and Environment. Springer-Verlag Berlin Heidelberg: 279.

Sztobryn M., Stigge H., Wielbińska D., Weidig B., Stanisławczyk I., Kańska A., Krzysztofik K., Kowalska B., Latkiewicz B., Mykita M., 2005. Storm surges In the southern Baltic Sea (Western and Central Parts). Berichte des BSH: 39.

Tylkowski, J., 2013. Temporal and spatial variability of air temperature and precipitation at the Polish coastal zone of the southern Baltic Sea. Baltica 26(1): 83-94.

Winowski M., 2008. Geomorfologiczne skutki tajania pokrywy śniegu na wybrzeżu klifowym wyspy Wolin. Landform Analysis 9: 222-225.

Winowski, M., 2009. Mechanism of the activities of rotational landslides on the cliff coast on the Wolin Island (north-west Poland). Quaestiones Geographicae 28(A/2): 101-111.

Wolski T., Wiśniewski B.,2014. Long-term, seasonal and short-term fluctuations in the water level of the Southern Baltic Sea. Quaestiones Geographicae 33(3): 181-197. 